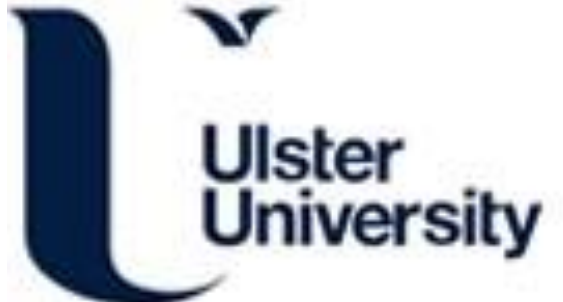

\section{The potential of siRNA based drug delivery in respiratory disorders: recent advances and progress}

Tambuwala, M. M. (2019). The potential of siRNA based drug delivery in respiratory disorders: recent advances and progress. Drug Development Research, 80(6), 714-730. https://doi.org/10.1002/ddr.21571

Link to publication record in Ulster University Research Portal

\author{
Published in: \\ Drug Development Research
}

Publication Status:

Published (in print/issue): 30/09/2019

DOI:

10.1002/ddr.21571

\section{Document Version}

Author Accepted version

\section{General rights}

Copyright for the publications made accessible via Ulster University's Research Portal is retained by the author(s) and / or other copyright owners and it is a condition of accessing these publications that users recognise and abide by the legal requirements associated with these rights.

\section{Take down policy}

The Research Portal is Ulster University's institutional repository that provides access to Ulster's research outputs. Every effort has been made to ensure that content in the Research Portal does not infringe any person's rights, or applicable UK laws. If you discover content in the Research Portal that you believe breaches copyright or violates any law, please contact pure-support@ulster.ac.uk. 
The potential of siRNA based drug delivery in respiratory disorders: recent advances and progress

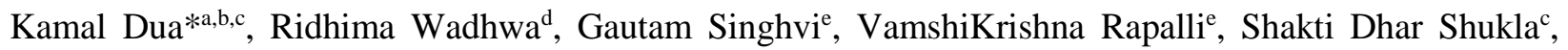
Madhur D. Shastrif, Gaurav Gupta ${ }^{\mathrm{g}}$, Saurabh Satija ${ }^{\mathrm{h}}$, Meenu Mehta ${ }^{\mathrm{h}}$, Navneet Khurana ${ }^{\mathrm{h}}$, Rajendra Awasthi ${ }^{i}$, Pawan Kumar Maurya ${ }^{j}$, Lakshmi Thangavelu ${ }^{k}$, S Rajesh Kumar ${ }^{k}$, Murtaza M. Tambuwala ${ }^{1}$ Trudi Collet ${ }^{\mathrm{m}}$, Philip M. Hansbro ${ }^{\mathrm{b}, \mathrm{c}, \mathrm{n}}$, Dinesh Kumar Chellappan ${ }^{\mathrm{o}, *}$

${ }^{a}$ Discipline of Pharmacy, Graduate School of Health, University of Technology Sydney, Ultimo NSW 2007, Australia.

${ }^{\mathrm{b} C e n t e n a r y ~ I n s t i t u t e, ~ R o y a l ~ P r i n c e ~ A l f r e d ~ H o s p i t a l, ~ C a m p e r d o w n, ~ N S W ~ 2050, ~ A u s t r a l i a . ~}$

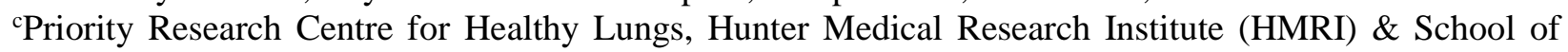
Biomedical Sciences and Pharmacy, University of Newcastle, Callaghan, NSW 2308, Australia.

${ }^{\mathrm{d} F a c u l t y}$ of Life Sciences and Biotechnology, South Asian University, Akbar Bhawan, Chanakyapuri, New Delhi 110021, India.

eDepartment of Pharmacy, Birla Institute of Technology and Science (BITS), Pilani, 333031, India

fSchool of Health Sciences, College of Health and Medicine, University of Tasmania, Launceston, Australia.

${ }^{\mathrm{g} S}$ School of Pharmaceutical Sciences, Jaipur National University, Jagatpura, 302017, Jaipur, India

hSchool of Pharmaceutical Sciences, Lovely Professional University, Jalandhar-Delhi G.T. Road (NH-1), Phagwara-144411, Punjab, India.

${ }^{i}$ Amity Institute of Pharmacy, Amity University, Sec. 125, Noida 201303, Uttar Pradesh, India

${ }^{j}$ Department of Biochemistry, Central University of Haryana, Jant-Pali, Mahendergarh District-123031, Haryana, India.

${ }^{\mathrm{k}}$ Nanobiomedicine Lab, Department of Pharmacology, Saveetha Dental College, Saveetha Institute of Medical and Technical Sciences, Chennai-600077, Tamil Nadu, India.

${ }^{\text {IS }}$ chool of Pharmacy and Pharmaceutical Sciences, Ulster University, Coleraine, County Londonderry, BT52 1SA, Northern Ireland, United Kingdom.

mInovative Medicines Group, Institute of Health \& Biomedical Innovation, Queensland University of Technology, Kelvin Grove, Brisbane, Queensland, Australia 4059.

${ }^{\mathrm{n} S}$ School of Life Sciences, University of Technology Sydney, Sydney, NSW 2007, Australia.

${ }^{\circ}$ Department of Life Sciences, School of Pharmacy, International Medical University, Bukit Jalil, Kuala Lumpur 57000, Malaysia.

\section{*Corresponding authors}

\section{Dr. Kamal Dua}

Discipline of Pharmacy, Graduate School of Health, University of Technology Sydney, P.O. Box: 123 Broadway, NSW 2007, Australia.

Tel: +61 2 95147387; E-mail: kamalpharmacist02@gmail.com

\section{Dr Dinesh Kumar Chellappan}

Department of Life Sciences, International Medical University, Bukit Jalil 57000, Kuala Lumpur, Malaysia

Tel: +60 126361308; E-mail: dineshkumarchellappan.imu@gmail.com, Dinesh_Kumar@imu.edu.my 


\section{$1 \quad$ Abstract}

2 Lung diseases are the leading cause of mortality worldwide. The currently available therapies are not 3 sufficient, leading to the urgent need for new therapies with sustained anti-inflammatory effects.

4 Small/short or silencing interfering RNA (siRNA) has potential therapeutic implications through post-

5 transcriptional downregulation of the target gene expression. siRNA is essential in gene regulation, so is

6 more favorable over other gene therapies due to its small size, high specificity, potency and no or low

7 immune response. In chronic respiratory diseases, local and targeted delivery of siRNA is achieved via

8 inhalation. The effectual delivery can be attained by the generation of aerosols via inhalers and nebulizers

9 which overcomes anatomical barriers, alveolar macrophage clearance and mucociliary clearance. In this

10 review, we discuss the different siRNA nanocarrier systems for chronic respiratory diseases, for safe and

11 effective delivery. siRNA mediated pro-inflammatory gene or miRNA targeting approach can be a useful

12 approach in combating chronic respiratory inflammatory conditions and thus providing sustained drug 13 delivery, reduced therapeutic dose, and improved patient compliance. This review will be of high 14 relevance to the formulation, biological and translational scientists working in the area of respiratory 15 diseases.

16 Keywords: siRNA; delivery systems; pulmonary; nanocarriers; RNA interference

17 


\section{1}

2 Chronic respiratory disease (CRD), in particular, asthma and chronic obstructive pulmonary disease

3 (COPD), are amongst the leading causes of mortality and morbidity that also exert huge health and

4 economic burden globally ("Global, regional, and national deaths, prevalence, disability-adjusted life

5 years, and years lived with disability for chronic obstructive pulmonary disease and asthma, 1990-2015: a

6 systematic analysis for the Global Burden of Disease Study 2015," 2017). Asthma is a complex and

7 heterogeneous chronic inflammatory disorder, primarily affecting the airways. The disease is largely

8 'allergic' in nature and is characterized by the upregulation of genes that lead to multiple inflammatory cascades implicated in asthma (Moheimani et al., 2016). Current asthma therapies focus on reduction of symptoms and limit exacerbations during the course of the disease. However, the proportion of asthmatics with the uncontrolled disease remain significantly high and utilizes the majority of healthcare expenses globally (P. M. Hansbro et al., 2017; Peters, Ferguson, Deniz, \& Reisner, 2006). Despite the increasing classification/categorization of asthmatics into various endotypes/phenotypes (based on a number of molecular biomarkers, clinical presentation and responsiveness to common therapies)(Fajt \& Wenzel, 2015), the key pathological feature of asthma is involvement of multiple inflammatory mediators that are often regulated by 'key' genes/proteins, which are also referred as master transcription regulators(Sel, Henke, Dietrich, Herz, \& Renz, 2006). Thus, targeting these key pro-inflammatory genes would potentially improve the overall disease outcomes(Sel et al., 2006).

COPD is another complex and multi-factorial respiratory disease that is caused primarily due to chronic exposure to cigarette smoking(Rennard \& Vestbo, 2006). In addition, exposures to biomass smoke, air pollution and a variety of occupational exposures to chemical dust and fumes also play an important role in the onset and progression of $\operatorname{COPD}(\mathrm{KC}$, Shukla, Gautam, Hansbro, \& O'Toole, 2018). COPD constitutes multiple inflammatory pathways, that are induced by chronic exposure to irritants and, in addition, due to an imbalance between the oxidase/anti-oxidant ratio and/or proteases/anti-proteases ratio (Peter J. Barnes, 2016). The course of the disease is further complicated by frequent acute exacerbations, which are described as worsening of disease symptoms that require a change of daily medications and often requiring hospitalizations(Rodriguez-Roisin, 2000). Acute exacerbations are primarily caused by infections (bacterial and/or viral) which dramatically increase the risk of mortality and morbidity amongst COPD patients(Sapey \& Stockley, 2006). In addition, the lack of effective therapies to limit the onset and/or progression of COPD further aids in increased global morbidity and mortality, especially in aging populations. 
1 Idiopathic pulmonary fibrosis (IPF) is a life-threatening lung disease that involves the progressive loss of

2 lung function along with clinically significant thickness/stiffness of lung tissues, generally accompanied

3 by tissue scarring. The 3- and 5-year mortality rates in IPF patients are almost 50\%(Meltzer \& Noble,

4 2008). Integrative network analysis revealed a total of 27 genes (CHIT1, CXCL14, LPPR4, etc.) and 22

5 miRNAs (in particular, miR-409-5p and has-miR-376c) that are associated with the disease

6 development(L. Wang, Huang, Zhang, Chen, \& Zhao, 2018). Targeting these and similar nucleic acids

7 that are crucial in the onset/progression of IPF would certainly lead to the development of novel therapies

8 for treating IPF and enhancing the quality of life in IPF patients.

9 Lung cancer is one of the leading causes of cancer-related mortality globally(Bray et al., 2018). A number

10 of genetic mutations have been linked to the pathogenesis of two major types of lung cancer, including 11 non-small-cell lung cancer (e.g., KRAS, EGFR, ALK, MET exon 14, BRAF, PIK3CA, ROS1, HER2, and

12 RET)("Comprehensive molecular profiling of lung adenocarcinoma," 2014) and squamous cell carcinoma

13 (PIK3CA, PTEN and amplification of FGFR1)(Rosell \& Karachaliou, 2016). Importantly, circulating

14 cell-free nucleic acids are now being investigated/utilized in both diagnosis and personalised treatments

15 for lung cancers, which have been reviewed in detail by Sorber et al.(Sorber et al., 2017). Given the immense burden and limited treatment options for lung cancer, nucleic acid-based therapies may present a novel therapeutic front to develop personalised therapies.

Respiratory infections, especially with viruses and bacteria, further complicate the course of chronic respiratory diseases. In particular, viral pathogens, such as rhinovirus, influenza virus and respiratory syncytial virus, are often implicated in the exacerbations of respiratory diseases, including asthma, COPD and IPF(Wark, Tooze, Powell, \& Parsons, 2013). In addition, bacterial pathogens (e.g., Haemophilus influenzae, Streptococcus pneumoniae, and Moraxella catarrhalis), either on its own or as a secondary pathogen following prior viral infections seem to be more detrimental to the lung health and poorer quality of life(Didierlaurent, Goulding, \& Hussell, 2007; Wark et al., 2013). A better understanding of the interactions between respiratory infections and chronic respiratory diseases (asthma, COPD) is essential for the design of more effective preventive and treatment strategies. For instance, tuberculosis seems to increase the risk of COPD and vice versa (O'Toole, Shukla, \& Walters, 2015). Moreover, tuberculosis increases the oxidative burden in the lungs (K. Dua et al., 2018; Shastri et al., 2018), regulated by multiple inflammatory mediators (K. Dua et al., 2019), that could be targeted with the novel, nucleic acidbased therapies for reducing the treatment regimens.

31 Despite the huge burden of major respiratory disease, there is a lack of effective treatments that could 32 limit the disease onset and/or disease progression(K Dua, DK Chellappan, et al., 2018; K Dua, Gupta, 
1 Chellappan, Shukla, \& Hansbro, 2018; Kamal Dua, Vamshi Krishna Rapalli, et al., 2018; Kamal Dua,

2 Shukla, de Jesus Andreoli Pinto, \& Hansbro, 2017; Rapalli et al., 2018). Thus, extensive research into 3 potentially novel therapeutics is urgently required. Currently, the potential of novel classes of 4 therapeutics, which are nucleic acid-based, for treating lung diseases is under intense investigation due to 5 their crucial roles in regulating gene expression(Kamal Dua, Terezinha de Jesus Andreoli Pinto, et al., 6 2018; Kamal Dua, Hansbro, Foster, \& Hansbro, 2017; Kamal Dua, Shukla, Tekade, \& Hansbro, 2017). 7 For instance, antisense oligonucleotides, which are single-strand DNAs or RNAs that selectively bind to 8 complementary mRNAs and modulate their functions, could potentially result in up-/down-regulation of 9 particular genes, thus aiding in limiting the disease progression (Bennett, Baker, Pham, Swayze, \& Geary, 10 2017). Similarly, small interference RNAs (siRNAs) are double-strand RNA molecules ( 21-23 base 11 pairs in length) capable to 'silence' specific genes of a known sequence responsible for genome 12 stability(J. K. Lam, Chow, Zhang, \& Leung, 2015). siRNA works at two stages: post-transcriptional gene 13 silencing (PTGS) resulting in direct sequence-specific cleavage causing repression of translation and degradation resulting in transcriptional gene silencing (TGS). siRNA is found associated with effector associations which are recognized by RNA-induced silencing complexes (RISCs)(Martinez, Patkaniowska, Urlaub, Lührmann, \& Tuschl, 2002). Further, this siRNA uses its full sequence for the recognition of the target sequence and cleaves the target mRNA (Jie Wang, Lu, Wientjes, \& Au, 2010). Micro RNAs (miRNAs) are single-stranded, endogenous non-coding RNA molecules ( 18-24 base pairs long). The miRNAs act as important regulators for a variety of immunological and cellular pathways (Awasthi, Madan, Malipeddi, Dua, \& Kulkarni, 2019; Hansbro \& Dua, 2018; D. D. Nguyen \& Chang, 2017).

Notably, siRNAs have been previously speculated to be an effective nucleic acid-based therapy in asthma(M. Choi, J. Gu, M. Lee, \& T. Rhim, 2017; Luo et al., 2012), COPD(Luo et al., 2012), IPF(C. N. D'Alessandro-Gabazza et al., 2012), lung cancer(Merkel, Rubinstein, \& Kissel, 2014) and respiratory infections(Merkel et al., 2014). We have attempted to primarily focus on the potential drug delivery strategies to enhance the efficacy of siRNAs in treating chronic respiratory diseases, because siRNA can result in multiple gene mutations (oncogenes and tumor suppressor genes) and acts as efficient and promising cure of disease in comparison to other therapies. RNA particles effectively enter the target, they may obstruct the expression of specific gene series through RNA interference (RNAi) to produce remedial impacts(Amreddy et al., 2018; Ayatollahi et al., 
2017). The greatest deterrent to translating siRNA treatment from the research facilities into the clinics is

2 delivery. A perfect delivery operator ought to shield the siRNA from enzymatic debasement, encourage

3 cell take-up and advance endosomal escape inside the cells, with irrelevant poisonous effect(V. Capel et

4 al., 2018; Jin et al., 2018). Pulmonary targeting could be accomplished by fundamental delivery or lung

5 delivery. The latter administrative route could possibly upgrade siRNA maintenance in the lungs and

6 lessen fundamental poisonous impacts. The delivery design should be planned cautiously so as to boost

7 the deposition of siRNA to the unhealthy region of the aviation routes. In majority of the lung siRNA

8 treatment studies in vivo, siRNA was conveyed either intranasally or intratracheally (Figure: 1) (I.

9 d'Angelo et al., 2018; Ding et al., 2018; He et al., 2018).

10 Limited studies have been reported on siRNA formulations via inhalation, although, it is expected for 11 potential future prospects. Following are the delivery systems of siRNA in pulmonary diseases:

\section{Lipid-based delivery vectors}

13 The lipid-based delivery system is generally used to deliver siRNA in vitro and in vivo. Ordinarily, 14 cationic lipids or liposomes utilizes negatively charged siRNA through electrostatic forces and are known 15 as lipoplexes. Several commercially available agents are lipid-based, some of which are for in vivo lung 16 delivery, for example, DharmFECT, lipofectamine, and Oligofectamine. The main difficulties of utilizing 17 lipid-based conveyance vectors in the clinical setup are their harmfulness and their non-specific activation of inflammatory cytokines and interferon reactions. Lipid-based delivery vectors can be classified into five types of molecules: Cationic lipoplexes and liposomes; PEGylated lipids; Neutral lipids; Lipids particles and Lipid-like molecules(Kaczmarek et al., 2018; Liu et al., 2019; Mokhtarieh, Lee, Kim, \& Lee, 2018; O. S. Muddineti, A. Shah, S. V. K. Rompicharla, B. Ghosh, \& S. Biswas, 2018).

\section{Polymer-based delivery vectors}

The polymer-based delivery vectors have an adaptable nature, which enables their physicochemical qualities to change effectively to accommodate their purpose. Also, it has been recommended that polymers usually do not induce a strong immune response (Ni et al., 2018; Otsuka et al., 2017). Polymerbased vectors are separated into two classes: polycations and polymeric nanoparticles. Engineered polycations, for example, polyamidoamine dendrimers and polyethyleneimine and natural polycations, for 2018).

\section{Peptide-based delivery vectors}


Since the discovery of TAT protein from HIV-1, which assista in the uptake of the virus in the cell, a range of cell-penetrating peptides (CPPs) have been identified. CPPs are most commonly utilized as

3 vehicles of restorative macromolecules. This technique can thus be used to deliver siRNA(Veilleux et al.,

4 2018; P. Y. Xu et al., 2018). CPPs and subsidiaries have been explored for siRNA conveyance which 5 include MPG, TAT, transportan, penetratin, CADY and LAH4. The peptides are either covalently 6 connected to siRNA through disulfide bond development or electrostatically in a non-covalent way(Yuan 7 et al., 2017; D. Zhang et al., 2018).

Airway inflammation is the major contributing factor in the pathogenesis of lung diseases, which corresponds to the degree of symptoms, airways hyper-responsiveness, and obstruction. Therefore, siRNA mediated delivery vehicle, as well as the products of secondary RNAi, stimulate the immune system by enhancing the expression or suppressing pro-inflammatory cytokines, interferons, and toll-like receptors via signaling pathways(Sioud, 2015). This is evident from an in vivo study for intratracheal administration of penetratin (peptide) conjugated siRNA capable of penetrating cytosol, activating several biochemical pathways and elevates the expression of TNF- $\alpha$, IL-12, and p40. It also activates the innate immune system to target p38 MAP kinase (Moschos et al., 2007).

The approach of siRNA based therapeutics against tuberculosis infections directs the gene expression modulation of the host rather than the bacilli(Man, Chow, Casettari, Gonzalez-Juarrero, \& Lam, 2016). The genes that regulate autophagy in the host can be targets for M. tuberculosis infection such as Rap22a, Bfl-1/A1, Ras homologue enriched in brain (Rheb) and UV radiation resistance associated genes (UVRAG) (Kathania, Raje, Raje, Dutta, \& Majumdar, 2011; Kim et al., 2015; Roberts, Chua, Kyei, \& Deretic, 2006; Jinli Wang et al., 2013). The suppression of these genes can hinder bacterial growth and proliferation. Another strategy is immunosuppression to inhibit bacterial growth. TNF- $\alpha$ and IFN $\gamma$ are essential for macrophage activation to initiate granuloma formation for the proliferation of $M$. tuberculosis (Ramakrishnan, 2012; Silva Miranda, Breiman, Allain, Deknuydt, \& Altare, 2012). Chemokine and Lymphotacin/XCL-1 activate $\mathrm{CD}^{+} \mathrm{T}$ cells during severe tuberculosis infection. In addition to this, XCL-1 regulates IFN- $\gamma$ and $\mathrm{CD}^{+}{ }^{+} \mathrm{T}$ cells to maintain granuloma. When siRNA targeting XCL-1 is delivered in TB infected mice, the expression of XCL-1 is greatly reduced, therefore, decreasing $\mathrm{T}$ lymphocytes, INF $\gamma$, and granuloma (Rosas-Taraco, Higgins, Sanchez-Campillo, et al., 2009).

The intranasal siRNA mediated delivery of SOC3 in chronic asthma mouse model had been reported to improve eosinophil count and airways hyper-responsiveness. This has also been correlated to improved 
mucus secretion, collagen reduction, and airway remodeling. siRNA mediated SOC3 reduces RhoA/Rho kinase signaling pathway, thereby, regulating inflammation, bronchial smooth muscle contractions and upregulating IL-13, IL-4 via RhoA protein and STAT6 activation. This reduces cytokine expression and airways hyper-responsiveness. It is known that IL-17 and IL-23 are responsible for neutrophilic and eosinophilic inflammation in mice (Figure.2)(Molet et al., 2001; Wakashin et al., 2008). Thus, siRNA mediated silencing of SOC3 regulates IL-17 expression(Staff, 2014).

\section{siRNA drug delivery in asthma/allergic airway diseases}

The combination therapy for asthma includes the use of inhaled corticosteroids, $\beta_{2}$ adrenergic receptor agonists, injected immunoglobulin $\mathrm{E}$ antibodies and quick-relief medications for effective control of asthma (Peter J Barnes, 2004). However, conventional inhaled corticosteroid therapies do not work in severe asthmatic patients (refractory asthma) and may cause adverse effects after long-term treatment (Kamal Dua, Hansbro, \& Hansbro, 2017; Philip M Hansbro et al., 2017; Mealey, Kenyon, Avdalovic, \& Louie, 2007). Therefore, more attention is needed in asthma research focused on the development of target-specific therapeutics. It has been previously reported that proteins such as chemokines(Rosenwasser, Zimmermann, Hershey, Foster, \& Rothenberg, 2003) and cytokines (Peter J Barnes, 2008) are involved in the asthmatic-inflammatory processes. Leukotrienes are also involved in the pathogenesis of asthma (Ogawa \& Calhoun, 2006).

Omalizumab (Xolair ${ }^{\circledR}$ - a monoclonal antibody against IgE), reslizumab (Cinqair ${ }^{\circledR}$ in the US and Cinqaero $^{\circledR}$ in Europe -a humanized antibody against human interleukin-5) and mepolizumab (Nucala ${ }^{\circledR}$ blocks interleukin-5) are commercially available potential targeted therapeutics to treat asthma (Catley, Coote, Bari, \& Tomlinson, 2011; Corren, 2012). Due to the complex nature of the disease, there is no single medication available for effective control of the asthmatic symptoms. Such targeted therapies may provide a valuable breakthrough in the pathophysiology of asthma and increase the possibility of decreasing asthma burden (M Choi, J Gu, M Lee, \& T Rhim, 2017; Cook \& Bochner, 2010).

siRNA delivery to the pulmonary system has ameliorated the therapeutic benefits of RNA interference (RNAi) for asthma (H.-Y. Huang \& Chiang, 2009). RNAi has been reported to be effective in blocking functions of molecular targets of asthma. siRNAs (21-23 bp in length) are involved in the sequencespecific degradation of messenger RNA (mRNA) and decrease the expression of the corresponding proteins (Agrawal et al., 2003; Xie \& Merkel, 2015). Prolonged lung retention of siRNA administered via the pulmonary route can reduce systemic side effects and improve the therapeutic benefits in the 
1 treatment of asthma (Deng et al., 2014; Rettig \& Behlke, 2012; Xie \& Merkel, 2015). Intranasal

2 administration of siRNA formulation with or without a transfection agent has been reported to inhibit

3 replication of the respiratory syncytial virus in mice models (Whitehead, Langer, \& Anderson, 2009).

4 Xie et al., (2016) developed a siRNA based delivery system, transferring polyethylenimine (Tf-PEI), to 5 target specific delivery of siRNAs and activated $\mathrm{T}$ cells in the lung. The optimized polyplexes possess 6 ideal physical properties such as zeta-potential, size, distribution and siRNA condensation efficiency. 7 Formulated polyplexes showed significant enhancement in cellular uptake and gene knockdown. 8 Biodistribution studies in murine asthmatic model confirmed effective delivery of siRNA to the activated 9 T cells (Xie et al., 2016). Based on the literature evidence, Xie and Merkel summarized that chemokines, 10 cytokines, tyrosine kinases, transcription factors, and co-stimulatory factors are the target of siRNA11 mediated asthma treatment. Further, the authors proposed potential applications of targeted siRNA 12 delivery to macrophages, T cells, and dendritic cells in asthma therapy (Xie \& Merkel, 2015).

13 Wang et al., 2008 reported imiquimod cream-chitosan nanoparticle system containing siRNA green 14 indicator (siGLO) or siRNA for natriuretic peptide receptor (siNPRA). The formulation was applied to 15 the mice skin. Fluorescence microscopy confirmed the delivery of SiGLO to the lungs via transdermal 16 route. OVA-sensitized asthmatic BALB/c mice model treated with imiquimodcream-siNPRA chitosan 17 nanoparticles showed significant $(<0.05)$ decrease in airway hyper-responsiveness, lung histopathology, 18 eosinophilia and pro-inflammatory cytokines IL-4 and IL-5 (X. Wang et al., 2008).

19 Packaging RNAs (pRNAs), a component of the bacteriophage phi29-packaging motor, have been used to 20 deliver signal transducer and activator of transcription (STAT5b) siRNA to asthmatic spleen 21 lymphocytes. Reverse transcription-polymerase chain reaction (RT-PCR) study showed that the STAT5b 22 gene mRNA expression was effectively inhibited by the pRNA dimer. It is suggested that pRNA dimer 23 carrying aptamer (ligand to interact with receptors) and siRNA can deliver functional siRNA to cells (C. 24 Qiu, Peng, Shi, \& Zhang, 2012). The first report on lung alveolar epithelial A549 cell targeting by 25 siRNA-generation four, amine-terminated poly (amidoamine) dendrimerdendriplexes and about $40 \%$ gene 26 silencing via siRNA exposed to the propellant used in oral inhalation devices was given by Conti et al., 27 (Conti, Brewer, Grashik, Avasarala, \& da Rocha, 2014).

28 Choi et al., developed dexamethasone and vitamin D binding protein (VDBP) siRNA combination 29 therapeutic system for the treatment of asthma. The results showed that the dexamethasone-conjugated 30 polyethyleneimine/ vitamin D binding protein (DEXA-PEI/VDBP) siRNA, reduced goblet cell 31 hyperplasia, ovalbumin sensitization, challenge-induced enhancement of airway inflammation, and 
expressions of interleukin-4 (IL-13), interleukin-4 (IL-4) and eosinophil mobilizing chemokine (CCL11)

2 (M Choi et al., 2017). Wu et al., investigated the ability of c-kit silenced siRNA to decrease the

3 inflammation caused by allergic asthma using asthmatic mouse model treated with intranasal anti-c-kit

4 siRNA. The result showed that siRNA significantly inhibited c-kit gene expression and decreased airway

5 mucus secretion. The production of stem cell factor, IL-4, and IL-5 declined significantly by c-kit siRNA.

6 However, no effect was recorded on interferon- $\gamma(\mathrm{IFN}-\gamma)$ generation (Wu et al., 2014).

7 Ambient particulate matters (PMs) are the major causative agents for asthma and chronic obstructive 8 pulmonary disease, by increasing mucus hypersecretion and inflammation. Wang et al., used ambient 9 particulate matter (PM)-exposed human bronchial epithelial cells (HBEC) to determine the function of 10 Amphiregulin (AREG), a ligand for epidermal growth factor receptor (EGFR), in PM-induced 11 inflammation and mucus hypersecretion. The AREG-siRNA significantly suppressed the PM-induced inflammation and mucus hypersecretion. This also suppressed the activation of the EGFR-AKT/ERK pathway (Jian Wang, Zhu, Wang, Chen, \& Song, 2019).

\section{siRNA drug delivery in lung cancer}

Lung cancer is the leading cause of death all over the world (Siegel, Naishadham, \& Jemal, 2012). The widely available therapies include chemotherapy, radiotherapy, and surgery, while, NSCLC treatment is majorly dependent on chemotherapy. Conventionally, chemotherapy has been practiced by intravenous (IV) administration. However, IV administration has side effects like bioavailability of the drug throughout the body via the bloodstream, which affects both malignant as well as healthy cells, the death of healthy cells causes adverse side effects like hair loss, fatigue and infections(Gandhi et al., 2018; Moding, Kastan, \& Kirsch, 2013). Dobashi et al., reported that the Akt/mTOR pathway is abnormally activated in NSCLC (Dobashi, Watanabe, Miwa, Suzuki, \& Koyama, 2011). Several tumor suppressors have been found to be mutated in NSCLC, proposing the function of mTOR pathway. Furthermore, the use of mTOR inhibitors is responsible for adverse side effects on healthy cells. Several molecular targeting drugs such as gefitinibcause inhibition of phosphorylation and tyrosine kinase activity of intracellular ATP binding domain of EGFR via competitive inhibition, erlotinib also inhibits tyrosine

27 kinase and bevacizumab inhibits angiogenesis (Y.K. Oh \& Park, 2009; Tiseo, Bartolotti, Gelsomino, \&

28 Bordi, 2010). Due to numerous side effects, there is an emerging need for therapeutics for the treatment of 29 lung cancer especially NSCLC (Sadowski, Kotulska, \& Jóźwiak, 2016). 
1 induce cell death, whereas, siRNA suppresses multi-drug resistance. Two types of siRNA were delivered

2 to improve efficacy; the first siRNA was targeting the MRP1 (Multidrug resistance-associated protein)

3 mRNA which is responsible for the suppression of main drug efflux transporter. The second siRNA was

4 targeting Bcl2 (B-cell lymphoma) mRNA, which suppresses cellular anti-apoptotic defense. The drug was

5 delivered to lungs by inhalation after encapsulation in NLCs. Inhalation leads to high accumulation of

6 nanocarriers in lungs whereas, intravenous injection led to major accumulation in liver, spleen, and

7 kidney compared to lungs. The developed NLC formulation effectively delivered the drug and siRNA

8 into cancer cells. This induced cell death of lung tumor cells by targeted gene silencing (Taratula,

9 Kuzmov, Shah, Garbuzenko, \& Minko, 2013).

$10 \mathrm{Xu}$ et al., studied the combined effect of doxorubicin and Bcl2 siRNA using polyethyleneimine as a 11 carrier for pulmonary delivery. Confocal laser scanning microscopy and flow cytometry exhibited a high 12 cellular uptake of drug and siRNA in B16F10 cell lines. Real-time polymerase chain reaction (RT-PCR) 13 observations had high gene silencing, where, $70 \%$ of Bcl2 mRNA were bashed down. The combination 14 has increased cell apoptosis and cell proliferation inhibition in B1F10 cells. The in-vivo studies in mice 15 showed high accumulation of doxorubicin and siRNA in metastatic lung cancer upon pulmonary delivery 16 (C.-N. Xu et al., 2017).

17 Hybrid lipid-polymer nanoparticles comprising of dipalmitoylphosphatidylcholine and poly(lactic-co18 glycolic) acid were developed to encapsulate siRNA. siGENOMESMART pool siRNA was used to check 19 their fate on the human epithelial airway barrier, which acts against $\alpha$ and $\beta$ subunits of the sodium trans 20 epithelial channel. The developed nanoparticles exhibited $\sim 150 \mathrm{~nm}$ hydrodynamic diameter, with $-25 \mathrm{mV}$ 21 zeta potential. In-vitro aerosolization studies were performed on a triple cell co-culture model which 22 mimic human epithelial airway barrier. There were no changes in nanoparticulate structure by 23 transmission electron microscopic imaging after nebulization. Nanoparticles were internalized in 24 epithelial cells and there were no cytotoxic effects or acute inflammation towards cell components. In25 vitro inhibition of sodium trans-epithelial channel protein expression was evaluated in A549 cell lines, 26 which confessed prolonged inhibition (Ivana d'Angelo et al., 2018).

27 Capel et al., reported delivery of siRNA using water-soluble piperazine substituted chitosan derivatives 28 for efficient delivery by inhalation. The piperazine derivative chitosan is water-soluble at physiological $29 \mathrm{pH}$, and forms nano-complexes with siRNA up to the size of 300nm at a relatively low polymer to siRNA 30 ratio (5:1). Glyceraldehyde-3-phosphate dehydrogenase (GADPH) targeting siRNA was complexed with 31 siRNA, in-vitro studies performed on lung epithelial cells revealed chitosan and siRNA complexes 32 exhibited silencing of a gene from $40-80 \%$. There was no effect of the aerosolization by PenCentury ${ }^{\mathrm{TM}}$ 
1 microsprayer device on particle size and integrity. In-vivo studies performed to determine the potential of

2 piperazine chitosan complex in subcutaneous bioluminescent tumor A540-lucxenograft model. There was

3 a significant reduction of the tumor with absence of adverse effects. The modified chitosan siRNA

4 complexes were found to be safe and had the potential to deliver by inhalation therapy (Victoria Capel et

5 al., 2018).

6 Ihara et.al., developed dry powdered chitosan siRNA complexes, and its gene silencing efficiency was 7 quantified histologically after intratracheal administration into murine lungs. EGFP-siRNA chitosan 8 complex efficacy was studied in EGFP transgenic mice and mice carrying metastatic lung cancer of 9 Lewis lung carcinoma. Transgenic mice are divided into three groups, where, one group was treated with 10 targeting siRNA, one group treated with non-targeting siRNA and one was left without any treatment. 11 The fluorescence in bronchus, bronchioles, alveolar walls of the group treated with targeting siRNA is 12 reduced to a large extent in comparison to mice group treated with non-targeting siRNA and group 13 without treatment. Similarly, the same results were observed in the metastatic lung tumor consisting of 14 mice groups. The results conclude a high extent of gene silencing in proximal airways compared to 15 peripheral lung tissues. The study proves pulmonary delivery of siRNA is a predominant approach to 16 target gene expression in respiratory disorders involving airways, parenchyma and lung cancers (Ihara et 17 al., 2015).

18 A dry powder siRNA based formulation was developed targeting vascular endothelial growth factors 19 (VEGF), which inhibits lung tumor growth in mice. In-vivo studies were performed on mice with 20 metastatic lung cancer, which were induced by B16F10 melanoma cells or Lewis lung carcinoma cells. 21 VEGF siRNA efficiency in gene suppression was evaluated by treating B16F10 and Lewis lung 22 carcinoma cell lines. There was reduced VEGF protein and mRNA pertaining to VEGF. In-vivo studies 23 were performed in tumor-bearing mice, where, chitosan was used to deliver siRNA. Prior to delivery of 24 siRNA, VEGF levels were measured in bronchoalveolar lavage fluid (BALF) collected from mice bearing 25 a tumor. The results showed reduced VEGF concentrations in BALF after single intratracheal 26 administration of dry siRNA powder. Repeated intratracheal administration reduced tumor growth in the 27 lungs. An in-vitro inhalation performance study was performed with jethaler single, which exhibited a 28 low-pressure drop. These results suggest chitosan dry powder of siRNA is a novel strategy for lung 29 cancer-specific and high gene silencing effect (Miwata et al., 2018).

30 Bohr and his co-workers developed phosphorus-based dendrimers for delivery of siRNA. Pyrrolidinium 31 and morpholinium were selected as protonated amino groups for better compatibility. The dendriplexes 32 form strong complexes with siRNA targeting tumor necrosis factor- $\alpha$ (TNF- $\alpha$ ). The in-vitro studies 
revealed high cellular uptake and in-vitro silencing efficiency of TNF- $\alpha$ in RAW264.7 lipopolysaccharide

2 activated macrophage cell line with pyrrolidiniumdendriplexes. The improved efficiency of pyrrolidinium

3 complexes is expected due to high pKa value which improves stronger siRNA complex formation. Nasal

4 administration of complexed dendriplexes has higher efficacy towards lung injury in comparison to non-

5 complexed siRNA (Table 1) (Bohr et al., 2017).

6 The RNAi mechanism and siRNA provides the potential for designing therapeutics for the treatment of

7 disease like cancer (Leung \& Whittaker, 2005). siRNA has intrinsic efficacy as it utilizes the endogenous

8 RNAi pathway, reduces the expression of disease-linked genes and can be used for any gene with its

9 complementary sequence(Vogelstein \& Kinzler, 2004). Several genes, their mutations, and pathways

10 have been found to be associated in different cancers, thus it is evident that siRNA can provide

11 therapeutic effect in cancers. siRNA mediated silencing of cancer associated proteins causes a remarkable

12 apoptotic effect (Pai et al., 2006). The major barriers for effective delivery of siRNA to the lungs are

13 complex branching of lungs associated with biomechanical barriers including mucus over the airways and

14 the airways cell membrane. Gene silencing will be achieved only when siRNA delivered is stable, is of

15 good concentration, penetrates the cell and reaches the cytoplasm (Durcan, Murphy, \& Cryan, 2008).

16 Zhang et al., reported siRNA counters K-RAS mutants and observed the anti-cancer effect by reducing K-

17 RAS in lung cancer cell line. Additionally, adenovirus-mediated siRNA precisely targets RAS and acts as

18 a drug for lung cancer treatment (Z. Zhang, Jiang, Yang, \& Wang, 2006). Han et al., proposed the use of p65 siRNA for anti-tumor effect by blocking PI3-kinase and NFאB(Han \& Roman, 2006).

Presently, in clinical trials, siRNA was locally administered to the target site to bypass the systemic delivery but the systemic route is required for the treatment of cancers and other diseases. For an in vivo delivery system, it ought to be biocompatible, non-immunogenic and biodegradable. The siRNA should be effectively delivered to the target site and must be protected from the action of serum nucleases. The system must evade from immediate hepatic or renal clearance and foster endosomal siRNA release into the cytoplasm for endogenous RISC interaction (Juliano, Alam, Dixit, \& Kang, 2008). Development and validation of different strategies of siRNA delivery are underway. Zhang et al., studies the in vitro delivery of encapsulated human double-minute gene 2-specific siRNA in arginine octamer surfacemodified liposomes. The complex was reported to be stable for 24 hours in blood and had potentially good transfection in different lung cancer cell lines (C. Zhang et al., 2006). Another study based on siRNA against human survivin was coated with cationic liposomes containing DOTAP and cholesterol (1:1 molar ratio) which resulted in LPD (liposome-polycation-DNA) nanoparticles. Further, LPD was PEGylated for ligand targeting and steric stabilization for selective delivery to the lungs. Further analysis suggested that PEGylated LPD has an anti-cancer effect via surviving downregulation(Li \& Huang, 
2006). In the in vivo mouse model, LPD nanoparticle encapsulating siRNA for epidermal growth factor

2 showed anti-tumor activity in combination with cisplatin on intravenous injection (Li, Chen, Hackett, \&

3 Huang, 2008). Biodegradable cationic poly (amino-ether) (mPAE) were accessed as a carrier for mTOR

$4 \quad$ siRNA for lower toxic effect, the prohibition against nuclease degradation and inhibition of cancer cell

5 proliferation (Gandhi et al., 2018). Chono et al., reported on the immunotoxicity and organ defects of

6 siRNA-LPD nanoparticle administration intravenously (Chono, Li, Conwell, \& Huang, 2008). Cationic

7 immune-liposomes conjugated with anti-transferrin receptor single chain antibody fragment with the

8 fluorescent label have been studied for systemic delivery for lung cancer metastasis. It was observed that

9 the labeled siRNA was distributed in lung metastasis rather than liver (Pirollo et al., 2006). Cationic

10 single-walled carbon nanotubes having siRNA for telomerase reverse transcriptase are being currently

11 studied as in vitro lung cancer models. In vitro internalization of siRNA suppresses target gene

12 expression. Furthermore, this model has also been reported for mice model for subcutaneous Lewis lung tumors (Zhuohan Zhang et al., 2006). Xu and his colleagues developed a pH-sensitive nanoparticulate system for co-delivery of doxorubicin and survivin siRNA. Doxorubicin was conjugated with polyethylenimine by a $\mathrm{pH}$-sensitive hydrazine bond using 3-maleimidopropionic acid hydrazide. The formed polyethyleneimine-doxorubicin -3- maleimidopropionic acid hydrazides are cationic in nature, and form complexes with anionic survivin siRNA with electrostatic interactions. On pulmonary delivery of these complexes in B16F10 tumor-bearing mice, resulted in the high accumulation of doxorubicin and siRNA in lungs. There was limited accumulation in case of normal lung tissues which indicates targeted drug delivery. The nanoparticulate system has improved anti-tumor efficacy in comparison to individual delivery of doxorubicin or surviving siRNA(C. Xu, Tian, Wang, Wang, \& Chen, 2016). A similar study was performed using Bcl2 siRNA with $\mathrm{pH}$-sensitive polyethyleneimine hydrazine doxorubicin complex. The in-vitro and in-vivo studies showed $\mathrm{pH}$ sensitive complex nanoparticles improved anti-tumor efficacy by pulmonary administration. There were high deposition and prolonged retention time in the lungs by pulmonary administration (C. Xu et al., 2015).

Self-assembled cholesterol conjugated chitosan nanoparticles were used to deliver curcumin and siRNA concurrently to achieve a synergistic effect against the cancer cells. Curcumin and siRNA were internalized by clathrin-dependent endocytosis in a time-dependent manner. This method was successful for A549 human lung carcinoma cell line for the co-delivery of siRNA and hydrophobic drug (Omkara Swami Muddineti, Aashma Shah, Sri Vishnu Kiran Rompicharla, Balaram Ghosh, \& Swati Biswas, 2018). Similarly, cationic polyethyleneimine-polylactic acid (PEI-PLA) was synthesized for systemic 32 delivery of paclitaxel and siRNA for the knockdown of survivin gene for lung carcinoma. Upon 33 nanoparticle uptake by the A549 cells, they turn electrically neutral due to lower endosomal $\mathrm{pH}$. These 
nanoparticles have $\mathrm{pH}$-responsive property as $\mathrm{pH} 5.5$ leads to drug release while $\mathrm{pH} 7.4$ for cellular

2 uptake. This study proved tumor growth inhibition along with surviving mRNA knockdown. Such co-

3 delivery systems provide large surface area for high drug loading, time-dependent drug release which

4 allows extended exposure to tumor treatment, passive targeting, lower cytotoxicity increased the

5 proliferative effect and anti-cancer activity (Jin et al., 2018) as depicted in the Figure:3.

6 Inhalation therapy can be potentially used for siRNA delivery due to high gene silencing effect and 7 sequence specificity. In vivo study on mice with Lewis lung carcinoma reveals the effect of intratracheal 8 vascular endothelial growth factor (VEGF) siRNA dry powder delivery downregulates the VEGF levels 9 in both tumor tissue as well as broncho-alveolar lavage and reduces the metastatic loci in lungs (Miwata et al., 2018). The aerosol composed of PEA and siRNA for Akt1 was administered in mice with urethaneinduced inhaled lung cancer. The use of aerosol for 4 weeks reduces Akt1 levels and inhibits the tumor progression (C.-X. Xu et al., 2008).

A drug called Excellair ${ }^{\mathrm{TM}}$ was developed by ZaBeCor Pharmaceuticals for the treatment of asthma. The drug targets mRNA of spleen tyrosine kinase (Syk) which is responsible for activation of several pro-inflammatory transcription factors. In the Phase I of the study, patients received siRNA Excellair ${ }^{\mathrm{TM}}$ via inhalation for 21 days (Watts \& Corey, 2010). The drug did not cause any side effects to the asthma patients and almost $75 \%$ of the patients reported improved breathing and reduction in the use of inhalers while placebo patients showed no improvement. Further, in 2009, Excellair ${ }^{\mathrm{TM}}$ entered Phase II of clinical trials but in 2015 it was discontinued as Syk can act as both suppressor and promoter of cell growth(Krisenko \& Geahlen, 2015). protein in respiratory syncytial virus (RVS) (DeVincenzo et al., 2010). ALN-RSV01 targets nucleocapsid $(\mathrm{N})$ protein of RSV which is essential for viral replication. In the Phase I of the clinical trial, 100 healthy males of 18 to 45 years age group were accounting to 65 having single and multiple dose of ALN-RSV01 while 36 were placebo. All the volunteers were given the therapeutic doses via nasal spray. No severe adverse effects were observed in different treated groups which lead ALN-RSV01 to enter Phase II (DeVincenzo et al., 2008). The Phase II study comprised of 85 healthy males of 18-45 years of age. All subjects received RSV01 inoculation at day 0 , and the ALN-RSV01 treated cohorts received the siRNA intranasal spray at days $-1,0$, 
$1+1,+2$, and +3 . A statistically significant reduction in detected RSV by quantitative culture and

2 real-time PCR was reported for patients receiving $150 \mathrm{mg}$ of study drug, the highest dosage

3 tested. Averaged for all treated patients vs. placebo, an acquisition over time effect was observed

4 by either PCR or quantitative culture. Indeed, the strongest effects of treatment with ALN-

5 RSV01 were observed by its prophylactic efficacy. The drug provided an antiviral effect over an

6 11-day time course, which resulted in reduced infection over time noticeable within 3-4 days

7 after inoculation (DeVincenzo et al., 2008). The safety trial for antiviral activity was conducted

8 for lung transplant patients with RSV. In Phase II b it was showed the safety of ALN-RSV01

9 treated RSV infections across the broader groups for lung transplant (Alvarez et al., 2009).

10 Atu-027 is composed of siRNA with lipoplex delivery system represents RNAi mediated 11 suppression of protein kinase N3 (PKN3) in vascular endothelial cells and prevents lung 12 metastasis. Phase Ib trials for the safety of Atu-027 with gemcitabine have been completed 13 (Schultheis et al., 2014).

14 Future prospects of drug delivery with siRNA in pulmonary diseases

15 RNA interference plays a key role in the treatment of several disorders. siRNA induces gene silencing by 16 acting on sequence-specific cleavage of complementary mRNA (messenger RNA) and thereby inhibiting 17 protein synthesis. siRNA based therapy was found to be a better strategy over the existing therapeutics, 18 such as drug molecules, monoclonal antibodies and proteins (Fujita, Takeshita, Kuwano, \& Ochiya, 19 2013). Apart from its advantages, administration and delivery of siRNA is the major challenge. siRNA 20 undergoes degradation in the presence of serum nucleases when they are administered directly into the 21 blood. Several strategies are utilized for delivery of siRNA to the target organ (T. Nguyen, Menocal, 22 Harborth, \& Fruehauf, 2008). siRNA demonstrated as potential therapeutic agents to treat pulmonary 23 disorders including lung cancer, infectious diseases, airway inflammatory diseases, and cystic fibrosis. 24 Delivery of siRNA directly by pulmonary route has added advantages such as reduced dose, reduced systemic side effects and reduced degradation due to a lower concentration of nuclease enzymes in airways. Pulmonary delivery of siRNA can also be helpful in systemic action, due to the large surface

27 area, thin epithelium and high vascularization in alveoli which favors rapid absorption of siRNA(Fujita et $a l ., 2013)$. Inhalation is the most preferred and easy mode of non-invasive administration which can be applied for siRNA by liquid aerosol or dry aerosol formulations. There is a need for a high attention regarding stability and biological activity of siRNA at the time of formulation development and delivery. However, the pulmonary delivery of these siRNA is challenging due to mucociliary clearance by ciliated 
1 epithelium cells, mucus, alveolar fluid and macrophages along the airways. Particles inhaled get deposited

2 on ciliated cells and eventually get cleared by cough and swallowed. The mucus secreted, form a thin film

3 thereby restricting diffusion and penetration of siRNA into the cell membrane. The alveolar fluids form a

4 thin film as a pulmonary surfactant (phospholipids and surfactant proteins) obstruct permeation efficiency

5 of lipid-based formulations to some extent and there was no effect in case of polymer-based systems.

6 Macrophages engulf the inhaled particles as part of the defense mechanism. There will be altered

7 conditions like increased mucus secretion, viscosity and ciliary clearance in diseased conditions. siRNA

8 with a negative charge and high molecular weight $(13 \mathrm{kDa})$, has also contributed to the poor ability to

9 cross cell membrane even it reaches the target surface area. Viral vectors and non-viral vectors are used

10 for the delivery of siRNA. Viral vectors are found to be more efficient to transfer genetic material into

11 host cells. Despite of its advantages, activation of immune responses after repeated administration may

12 lead to organ failure and chances of serious concerns. Non-viral vectors which include lipids, polymers,

13 inorganic materials and transfection agents (i.e., Lipofectamine, Oligofectamine, TransIT-TKO and

14 DharmaFECT) are more vastly utilized for siRNA delivery. The ideal characteristic feature for a siRNA

15 delivery system should include a) Protection from enzymatic degradation, b) Ability to penetrate cell

16 membrane (facilitate cell uptake) c) It should able to protect from endosomal degradation and induce gene

17 silencing d) Should not affect siRNA activity and specificity e) Non-toxic (Feldmann \& Merkel, 2015; J.

18 K.-W. Lam, Liang, \& Chan, 2012; Yingshan Qiu, Lam, Leung, \& Liang, 2016; Youngren-Ortiz, Gandhi,

19 España-Serrano, \& Chougule, 2016, 2017). Several strategies are utilized to overcome stated challenges

20 in the delivery of siRNA some of them are discussed below.

\section{Conclusion}

22 The potential siRNA based therapeutics for lung diseases have to be explored further. The nanoparticle23 based inhalable and aerosols have been studied extensively for improved delivery and clinical efficiency. 24 Therefore, ex vivo models for inhaled particulate distribution and in vivo models for 25 pharmacokinetics/pharmacodynamics are being taken under consideration to understand their distribution, 26 safety, and efficiency of siRNA in the pulmonary system. Different organic and inorganic nanoparticle 27 with varied size, charge, and chemistry have been used as carriers of siRNA or siRNA drug conjugate 28 delivery. Also, upon internalization at the target site siRNA should be able to escape the endosomal 29 mechanism. Furthermore, a nanoparticle with small size have been preferred for longevity at the target 30 site, non-specific interactions and to prevent the off-site toxic effect.

\section{Acknowledgements}


PMH is funded by a Fellowship from the National Health Medical Research Council, NHMRC (1079187). We would like to acknowledge NHMRC and the Graduate School of Health (GSH), University of Technology Sydney (UTS), NSW, Australia for the funding.

\section{References}

Agrawal, N., Dasaradhi, P., Mohmmed, A., Malhotra, P., Bhatnagar, R. K., \& Mukherjee, S. K. (2003). RNA interference: biology, mechanism, and applications. Microbiology and molecular biology reviews, 67(4), 657-685.

Alvarez, R., Elbashir, S., Borland, T., Toudjarska, I., Hadwiger, P., John, M., . . Kahn, J. (2009). RNA interference-mediated silencing of the respiratory syncytial virus nucleocapsid defines a potent antiviral strategy. Antimicrobial agents and chemotherapy, 53(9), 3952-3962.

Amreddy, N., Babu, A., Panneerselvam, J., Srivastava, A., Muralidharan, R., Chen, A., . . Ramesh, R. (2018). Chemo-biologic combinatorial drug delivery using folate receptor-targeted dendrimer nanoparticles for lung cancer treatment. Nanomedicine, 14(2), 373-384. doi:10.1016/j.nano.2017.11.010

Asai-Tajiri, Y., Matsumoto, K., Fukuyama, S., Kan-o, K., Nakano, T., Tonai, K., . . Nakanishi, Y. (2014). Small interfering RNA against CD86 during allergen challenge blocks experimental allergic asthma. Respiratory research, 15(1), 132.

Awasthi, R., Madan, J. R., Malipeddi, H., Dua, K., \& Kulkarni, G. T. (2019). Therapeutic strategies for targeting non-coding RNAs with special emphasis on novel delivery systems. Non-coding RNA Investigation, 3.

Ayatollahi, S., Salmasi, Z., Hashemi, M., Askarian, S., Oskuee, R. K., Abnous, K., \& Ramezani, M. (2017). Aptamer-targeted delivery of Bcl-xL shRNA using alkyl modified PAMAM dendrimers into lung cancer cells. Int J Biochem Cell Biol, 92, 210-217. doi:10.1016/j.biocel.2017.10.005

Barnes, P. J. (2004). New drugs for asthma. Nature reviews Drug discovery, 3(10), 831.

Barnes, P. J. (2008). The cytokine network in asthma and chronic obstructive pulmonary disease. The Journal of clinical investigation, 118(11), 3546-3556.

Barnes, P. J. (2016). Inflammatory mechanisms in patients with chronic obstructive pulmonary disease. Journal of Allergy and Clinical Immunology, 138(1), 16-27. doi:10.1016/j.jaci.2016.05.011

Bennett, C. F., Baker, B. F., Pham, N., Swayze, E., \& Geary, R. S. (2017). Pharmacology of Antisense Drugs. Annu Rev Pharmacol Toxicol, 57, 81-105. doi:10.1146/annurev-pharmtox-010716-104846

Bitko, V., Musiyenko, A., Shulyayeva, O., \& Barik, S. (2005). Inhibition of respiratory viruses by nasally administered siRNA. Nature medicine, 11(1), 50.

Bohr, A., Tsapis, N., Andreana, I., Chamarat, A., Foged, C., Delomenie, C., . . Mignani, S. (2017). AntiInflammatory Effect of Anti-TNF- $\alpha$ SiRNA Cationic Phosphorus Dendrimer Nanocomplexes Administered Intranasally in a Murine Acute Lung Injury Model. Biomacromolecules, 18(8), 2379-2388.

Bray, F., Ferlay, J., Soerjomataram, I., Siegel, R. L., Torre, L. A., \& Jemal, A. (2018). Global cancer statistics 2018: GLOBOCAN estimates of incidence and mortality worldwide for 36 cancers in 185 countries. CA Cancer J Clin, 68(6), 394-424. doi:10.3322/caac.21492

Capel, V., Vllasaliu, D., Watts, P., Clarke, P. A., Luxton, D., Grabowska, A. M., . . Stolnik, S. (2018). Watersoluble substituted chitosan derivatives as technology platform for inhalation delivery of siRNA. Drug Deliv, 25(1), 644-653. doi:10.1080/10717544.2018.1440668 
Capel, V., Vllasaliu, D., Watts, P., Clarke, P. A., Luxton, D., Grabowska, A. M., . . Stolnik, S. (2018). Watersoluble substituted chitosan derivatives as technology platform for inhalation delivery of siRNA. Drug delivery, 25(1), 644-653.

Catley, M. C., Coote, J., Bari, M., \& Tomlinson, K. L. (2011). Monoclonal antibodies for the treatment of asthma. Pharmacology \& therapeutics, 132(3), 333-351.

Choi, M., Gu, J., Lee, M., \& Rhim, T. (2017). A new combination therapy for asthma using dual-function dexamethasone-conjugated polyethylenimine and vitamin D binding protein siRNA. Gene Ther, 24(11), 727-734. doi:10.1038/gt.2017.83

Choi, M., Gu, J., Lee, M., \& Rhim, T. (2017). A new combination therapy for asthma using dual-function dexamethasone-conjugated polyethylenimine and vitamin D binding protein siRNA. Gene therapy, 24(11), 727.

Chono, S., Li, S.-D., Conwell, C. C., \& Huang, L. (2008). An efficient and low immunostimulatory nanoparticle formulation for systemic siRNA delivery to the tumor. Journal of Controlled Release, 131(1), 64-69.

Chow, M. Y., Qiu, Y., Lo, F. F., Lin, H. H., Chan, H.-K., Kwok, P. C., \& Lam, J. K. (2017). Inhaled powder formulation of naked siRNA using spray drying technology with L-leucine as dispersion enhancer. International journal of pharmaceutics, 530(1-2), 40-52.

Comprehensive molecular profiling of lung adenocarcinoma. (2014). Nature, 511(7511), 543-550. doi:10.1038/nature13385

Conde, J., Tian, F., Hernández, Y., Bao, C., Cui, D., Janssen, K.-P., . . J Jesús, M. (2013). In vivo tumor targeting via nanoparticle-mediated therapeutic siRNA coupled to inflammatory response in lung cancer mouse models. Biomaterials, 34(31), 7744-7753.

Conti, D. S., Brewer, D., Grashik, J., Avasarala, S., \& da Rocha, S. R. (2014). Poly (amidoamine) dendrimer nanocarriers and their aerosol formulations for siRNA delivery to the lung epithelium. Molecular pharmaceutics, 11(6), 1808-1822.

Cook, M. L., \& Bochner, B. S. (2010). Update on biological therapeutics for asthma. World Allergy Organization Journal, 3(6), 188.

Corren, J. (2012). Inhibition of interleukin-5 for the treatment of eosinophilic diseases. Discovery medicine, 13(71), 305-312.

D'Alessandro-Gabazza, C. N., Kobayashi, T., Boveda-Ruiz, D., Takagi, T., Toda, M., Gil-Bernabe, P., ... Suzuki, N. (2012). Development and preclinical efficacy of novel transforming growth factor- $\beta 1$ short interfering RNAs for pulmonary fibrosis. American journal of respiratory cell and molecular biology, 46(3), 397-406.

D'Alessandro-Gabazza, C. N., Kobayashi, T., Boveda-Ruiz, D., Takagi, T., Toda, M., Gil-Bernabe, P., ... Gabazza, E. C. (2012). Development and preclinical efficacy of novel transforming growth factorbeta1 short interfering RNAs for pulmonary fibrosis. Am J Respir Cell Mol Biol, 46(3), 397-406. doi:10.1165/rcmb.2011-01580C

d'Angelo, I., Costabile, G., Durantie, E., Brocca, P., Rondelli, V., Russo, A., . . Petri-Fink, A. (2018). Hybrid Lipid/Polymer Nanoparticles for Pulmonary Delivery of siRNA: Development and Fate Upon In Vitro Deposition on the Human Epithelial Airway Barrier. Journal of aerosol medicine and pulmonary drug delivery, 31(3), 170-181.

d'Angelo, I., Costabile, G., Durantie, E., Brocca, P., Rondelli, V., Russo, A., . . Ungaro, F. (2018). Hybrid Lipid/Polymer Nanoparticles for Pulmonary Delivery of siRNA: Development and Fate Upon In Vitro Deposition on the Human Epithelial Airway Barrier. J Aerosol Med Pulm Drug Deliv, 31(3), 170-181. doi:10.1089/jamp.2017.1364

Darcan-Nicolaisen, Y., Meinicke, H., Fels, G., Hegend, O., Haberland, A., Kühl, A., . . Henke, W. (2009). Small interfering RNA against transcription factor STAT6 inhibits allergic airway inflammation and hyperreactivity in mice. The Journal of Immunology, 182(12), 7501-7508. 
Deng, Y., Wang, C. C., Choy, K. W., Du, Q., Chen, J., Wang, Q., . . Tang, T. (2014). Therapeutic potentials of gene silencing by RNA interference: principles, challenges, and new strategies. Gene, 538(2), 217-227.

DeVincenzo, J., Cehelsky, J. E., Alvarez, R., Elbashir, S., Harborth, J., Toudjarska, I., . . Vaishnaw, A. K. (2008). Evaluation of the safety, tolerability and pharmacokinetics of ALN-RSV01, a novel RNAi antiviral therapeutic directed against respiratory syncytial virus (RSV). Antiviral research, 77(3), 225-231.

DeVincenzo, J., Lambkin-Williams, R., Wilkinson, T., Cehelsky, J., Nochur, S., Walsh, E., ... Vaishnaw, A. (2010). A randomized, double-blind, placebo-controlled study of an RNAi-based therapy directed against respiratory syncytial virus. Proceedings of the National Academy of Sciences, 107(19), 8800-8805.

Didierlaurent, A., Goulding, J., \& Hussell, T. (2007). The impact of successive infections on the lung microenvironment. Immunology, 122(4), 457-465. doi:10.1111/j.1365-2567.2007.02729.x

Ding, L., Zhu, C., Yu, F., Wu, P., Chen, G., Ullah, A., . . Oupicky, D. (2018). Pulmonary delivery of polyplexes for combined PAI-1 gene silencing and CXCR4 inhibition to treat lung fibrosis. Nanomedicine, 14(6), 1765-1776. doi:10.1016/j.nano.2018.05.005

Dobashi, Y., Watanabe, Y., Miwa, C., Suzuki, S., \& Koyama, S. (2011). Mammalian target of rapamycin: a central node of complex signaling cascades. International journal of clinical and experimental pathology, 4(5), 476.

Dua, K., Chellappan, D., Singhvi, G., de Jesus, A. P. T., Gupta, G., \& Hansbro, P. (2018). Targeting microRNAs using nanotechnology in pulmonary diseases. Panminerva medica, 60(4), 230.

Dua, K., de Jesus Andreoli Pinto, T., Chellappan, D. K., Gupta, G., Bebawy, M., \& Hansbro, P. M. (2018). Advancements in nano drug delivery systems: a challenge for biofilms in respiratory diseases. Panminerva medica.

Dua, K., Gupta, G., Chellappan, D., Shukla, S., \& Hansbro, P. (2018). Targeting bacterial biofilms in pulmonary diseases in pediatric population. Minerva pediatrica.

Dua, K., Hansbro, N. G., Foster, P. S., \& Hansbro, P. M. (2017). MicroRNAs as therapeutics for future drug delivery systems in treatment of lung diseases. Drug delivery and translational research, 7(1), 168-178.

Dua, K., Hansbro, N. G., \& Hansbro, P. M. (2017). Steroid resistance and concomitant respiratory infections: A challenging battle in pulmonary clinic. EXCLI journal, 16, 981.

Dua, K., Malyla, V., Singhvi, G., Wadhwa, R., Krishna, R. V., Shukla, S. D., . . Hansbro, P. M. (2019). Increasing complexity and interactions of oxidative stress in chronic respiratory diseases: An emerging need for novel drug delivery systems. Chem Biol Interact, 299, 168-178. doi:10.1016/j.cbi.2018.12.009

Dua, K., Rapalli, V. K., Shukla, S. D., Singhvi, G., Shastri, M. D., Chellappan, D. K., . . Pinto, T. D. J. A. (2018). Multi-drug resistant Mycobacterium tuberculosis \& oxidative stress complexity: Emerging need for novel drug delivery approaches. Biomedicine \& Pharmacotherapy, 107, 12181229.

Dua, K., Rapalli, V. K., Shukla, S. D., Singhvi, G., Shastri, M. D., Chellappan, D. K., . . Hansbro, P. M. (2018). Multi-drug resistant Mycobacterium tuberculosis \& oxidative stress complexity: Emerging need for novel drug delivery approaches. Biomed Pharmacother, 107, 1218-1229. doi:10.1016/j.biopha.2018.08.101

Dua, K., Shukla, S. D., de Jesus Andreoli Pinto, T., \& Hansbro, P. M. (2017). Nanotechnology: Advancing the translational respiratory research. Interventional Medicine and Applied Science, 9(1), 39-41.

Dua, K., Shukla, S. D., Tekade, R. K., \& Hansbro, P. M. (2017). Whether a novel drug delivery system can overcome the problem of biofilms in respiratory diseases? Drug delivery and translational research, 7(1), 179-187. 
Durcan, N., Murphy, C., \& Cryan, S.-A. (2008). Inhalable siRNA: potential as a therapeutic agent in the lungs. Molecular pharmaceutics, 5(4), 559-566.

Fajt, M. L., \& Wenzel, S. E. (2015). Asthma phenotypes and the use of biologic medications in asthma and allergic disease: the next steps toward personalized care. J Allergy Clin Immunol, 135(2), 299-310; quiz 311. doi:10.1016/j.jaci.2014.12.1871

Feldmann, D. P., \& Merkel, O. M. (2015). The advantages of pulmonary delivery of therapeutic siRNA. Therapeutic delivery, 6(4), 407-409.

Fujita, Y., Takeshita, F., Kuwano, K., \& Ochiya, T. (2013). RNAi therapeutic platforms for lung diseases. Pharmaceuticals, 6(2), 223-250.

Gandhi, N. S., Godeshala, S., Koomoa-Lange, D.-L. T., Miryala, B., Rege, K., \& Chougule, M. B. (2018). Bioreducible Poly (Amino Ethers) Based mTOR siRNA Delivery for Lung Cancer. Pharmaceutical research, 35(10), 188.

Global, regional, and national deaths, prevalence, disability-adjusted life years, and years lived with disability for chronic obstructive pulmonary disease and asthma, 1990-2015: a systematic analysis for the Global Burden of Disease Study 2015. (2017). Lancet Respir Med, 5(9), 691-706. doi:10.1016/s2213-2600(17)30293-x

Goh, F. Y., Cook, K. L., Upton, N., Tao, L., Lah, L. C., Leung, B. P., \& Wong, W. F. (2013). Receptorinteracting protein 2 gene silencing attenuates allergic airway inflammation. The Journal of Immunology, 1202416.

Han, S., \& Roman, J. (2006). Fibronectin induces cell proliferation and inhibits apoptosis in human bronchial epithelial cells: pro-oncogenic effects mediated by PI3-kinase and NF-kB. Oncogene, 25(31), 4341.

Hansbro, P. M., \& Dua, K. (2018). Rajendra Awasthi, Anurag Kumar Singh, Gaurav Mishra, Anand Maurya, Dinesh Kumar Chellappan, Gaurav Gupta. Circular RNAs: Biogenesis and Functions, $1087,1$.

Hansbro, P. M., Kim, R. Y., Starkey, M. R., Donovan, C., Dua, K., Mayall, J. R., . . Wood, L. G. (2017). Mechanisms and treatments for severe, steroid-resistant allergic airway disease and asthma. Immunological reviews, 278(1), 41-62.

Hansbro, P. M., Kim, R. Y., Starkey, M. R., Donovan, C., Dua, K., Mayall, J. R., . . Horvat, J. C. (2017). Mechanisms and treatments for severe, steroid-resistant allergic airway disease and asthma. Immunol Rev, 278(1), 41-62. doi:10.1111/imr.12543

He, M., Li, K., Yu, C., Lv, B., Zhao, N., Deng, J., . . Wang, L. (2018). In vitro study of FUZ as a novel potential therapeutic target in non-small-cell lung cancer. Life Sci, 197, 91-100. doi:10.1016/j.Ifs.2018.02.007

Hong, S.-H., Minai-Tehrani, A., Chang, S.-H., Jiang, H.-L., Lee, S., Lee, A.-Y., . . Cho, M.-H. (2014). Correction: Knockdown of the Sodium-Dependent Phosphate Co-Transporter 2b (NPT2b) Suppresses Lung Tumorigenesis. PloS one, 9(1), 10.1371/annotation/08286cd08288-08527f08284f08214-08856f-57267107efa57267108.

Howard, K. A., Rahbek, U. L., Liu, X., Damgaard, C. K., Glud, S. Z., Andersen, M. Ø., . . Besenbacher, F. (2006). RNA interference in vitro and in vivo using a novel chitosan/siRNA nanoparticle system. Molecular Therapy, 14(4), 476-484.

Huang, H.-Y., \& Chiang, B.-L. (2009). siRNA as a therapy for asthma. Current opinion in molecular therapeutics, 11(6), 652-663.

Huang, Z.-Y., Kim, M.-K., Kim-Han, T.-H., Indik, Z. K., \& Schreiber, A. D. (2013). Effect of locally administered Syk siRNA on allergen-induced arthritis and asthma. Molecular immunology, 53(1), 52-59.

Ihara, D., Hattori, N., Horimasu, Y., Masuda, T., Nakashima, T., Senoo, T., . . Kohno, N. (2015). Histological quantification of gene silencing by intratracheal administration of dry powdered 
small-interfering RNA/chitosan complexes in the murine lung. Pharmaceutical research, 32(12), 3877-3885.

Jin, M., Jin, G., Kang, L., Chen, L., Gao, Z., \& Huang, W. (2018). Smart polymeric nanoparticles with pHresponsive and PEG-detachable properties for co-delivering paclitaxel and survivin siRNA to enhance antitumor outcomes. International journal of nanomedicine, 13, 2405.

Juliano, R., Alam, M. R., Dixit, V., \& Kang, H. (2008). Mechanisms and strategies for effective delivery of antisense and siRNA oligonucleotides. Nucleic acids research, 36(12), 4158-4171.

Kaczmarek, J. C., Kauffman, K. J., Fenton, O. S., Sadtler, K., Patel, A. K., Heartlein, M. W., . . Anderson, D. G. (2018). Optimization of a Degradable Polymer-Lipid Nanoparticle for Potent Systemic Delivery of mRNA to the Lung Endothelium and Immune Cells. Nano Lett, 18(10), 6449-6454. doi:10.1021/acs.nanolett.8b02917

Kathania, M., Raje, C. I., Raje, M., Dutta, R. K., \& Majumdar, S. (2011). Bfl-1/A1 acts as a negative regulator of autophagy in mycobacteria infected macrophages. The international journal of biochemistry \& cell biology, 43(4), 573-585.

KC, R., Shukla, S. D., Gautam, S. S., Hansbro, P. M., \& O'Toole, R. F. (2018). The role of environmental exposure to non-cigarette smoke in lung disease. Clinical and Translational Medicine, 7(1), 39. doi:10.1186/s40169-018-0217-2

Khaitov, M. R., Shilovskiy, I. P., Nikonova, A. A., Shershakova, N. N., Kamyshnikov, O. Y., Babakhin, A. A., . .. Khaitov, R. M. (2014). Small interfering RNAs targeted to interleukin-4 and respiratory syncytial virus reduce airway inflammation in a mouse model of virus-induced asthma exacerbation. Human gene therapy, 25(7), 642-650.

Kim, J. K., Yuk, J.-M., Kim, S. Y., Kim, T. S., Jin, H. S., Yang, C.-S., \& Jo, E.-K. (2015). MicroRNA-125a inhibits autophagy activation and antimicrobial responses during mycobacterial infection. The Journal of Immunology, 194(11), 5355-5365.

Krisenko, M. O., \& Geahlen, R. L. (2015). Calling in SYK: SYK's dual role as a tumor promoter and tumor suppressor in cancer. Biochimica et Biophysica Acta (BBA) - Molecular Cell Research, 1853(1), 254-263. doi:https://doi.org/10.1016/j.bbamcr.2014.10.022

Lam, J. K.-W., Liang, W., \& Chan, H.-K. (2012). Pulmonary delivery of therapeutic siRNA. Advanced drug delivery reviews, 64(1), 1-15.

Lam, J. K., Chow, M. Y., Zhang, Y., \& Leung, S. W. (2015). siRNA Versus miRNA as Therapeutics for Gene Silencing. Mol Ther Nucleic Acids, 4, e252. doi:10.1038/mtna.2015.23

Leung, R. K., \& Whittaker, P. A. (2005). RNA interference: from gene silencing to gene-specific therapeutics. Pharmacology \& therapeutics, 107(2), 222-239.

Li, S.-D., Chen, Y.-C., Hackett, M. J., \& Huang, L. (2008). Tumor-targeted delivery of siRNA by selfassembled nanoparticles. Molecular Therapy, 16(1), 163-169.

Li, S.-D., \& Huang, L. (2006). Targeted delivery of antisense oligodeoxynucleotide and small interference RNA into lung cancer cells. Molecular pharmaceutics, 3(5), 579-588.

Liu, Q., Wang, D., Xu, Z., Huang, C., Zhang, C., He, B., . . Qian, H. (2019). Targeted delivery of Rab26 siRNA with precisely tailored DNA prism for lung cancer therapy. Chembiochem. doi:10.1002/cbic.201800761

Lomas-Neira, J., Perl, M., Venet, F., Chung, C.-S., \& Ayala, A. (2012). The role and source of TNF- $\alpha$ in hemorrhage induced priming for septic lung injury. Shock (Augusta, Ga.), 37(6), 611.

Luo, Y., Zhai, X., Ma, C., Sun, P., Fu, Z., Liu, W., \& Xu, J. (2012). An inhalable beta(2)-adrenoceptor liganddirected guanidinylated chitosan carrier for targeted delivery of siRNA to lung. J Control Release, 162(1), 28-36. doi:10.1016/j.jconrel.2012.06.005

Man, D. K., Chow, M. Y., Casettari, L., Gonzalez-Juarrero, M., \& Lam, J. K. (2016). Potential and development of inhaled RNAi therapeutics for the treatment of pulmonary tuberculosis. Advanced drug delivery reviews, 102, 21-32. 
Martinez, J., Patkaniowska, A., Urlaub, H., Lührmann, R., \& Tuschl, T. (2002). Single-stranded antisense siRNAs guide target RNA cleavage in RNAi. Cell, 110(5), 563-574.

Mealey, F. H., Kenyon, N. J., Avdalovic, M. V., \& Louie, S. (2007). Difficult-to-control asthma in adults. The American journal of medicine, 120(9), 760-763.

Meltzer, E. B., \& Noble, P. W. (2008). Idiopathic pulmonary fibrosis. Orphanet J Rare Dis, 3, 8. doi:10.1186/1750-1172-3-8

Merkel, O. M., Rubinstein, I., \& Kissel, T. (2014). siRNA delivery to the lung: what's new? Adv Drug Deliv Rev, 75, 112-128. doi:10.1016/j.addr.2014.05.018

Miwata, K., Okamoto, H., Nakashima, T., Ihara, D., Horimasu, Y., Masuda, T., . . Hamada, H. (2018). Intratracheal Administration of siRNA Dry Powder Targeting Vascular Endothelial Growth Factor Inhibits Lung Tumor Growth in Mice. Molecular Therapy-Nucleic Acids, 12, 698-706.

Moding, E. J., Kastan, M. B., \& Kirsch, D. G. (2013). Strategies for optimizing the response of cancer and normal tissues to radiation. Nature reviews Drug discovery, 12(7), 526.

Moheimani, F., Hsu, A. C., Reid, A. T., Williams, T., Kicic, A., Stick, S. M., . . Knight, D. A. (2016). The genetic and epigenetic landscapes of the epithelium in asthma. Respir Res, 17(1), 119. doi:10.1186/s12931-016-0434-4

Mokhtarieh, A. A., Lee, J., Kim, S., \& Lee, M. K. (2018). Preparation of siRNA encapsulated nanoliposomes suitable for siRNA delivery by simply discontinuous mixing. Biochim Biophys Acta Biomembr, 1860(6), 1318-1325. doi:10.1016/j.bbamem.2018.02.027

Molet, S., Hamid, Q., Davoineb, F., Nutku, E., Tahaa, R., Pagé, N., . . Chakir, J. (2001). IL-17 is increased in asthmatic airways and induces human bronchial fibroblasts to produce cytokines. Journal of Allergy and Clinical Immunology, 108(3), 430-438.

Moschos, S. A., Jones, S. W., Perry, M. M., Williams, A. E., Erjefalt, J. S., Turner, J. J., . . Lindsay, M. A. (2007). Lung delivery studies using siRNA conjugated to TAT (48-60) and penetratin reveal peptide induced reduction in gene expression and induction of innate immunity. Bioconjugate chemistry, 18(5), 1450-1459.

Muddineti, O. S., Shah, A., Rompicharla, S. V. K., Ghosh, B., \& Biswas, S. (2018). Cholesterol-grafted chitosan micelles as a nanocarrier system for drug-siRNA co-delivery to the lung cancer cells. International journal of biological macromolecules, 118, 857-863.

Muddineti, O. S., Shah, A., Rompicharla, S. V. K., Ghosh, B., \& Biswas, S. (2018). Cholesterol-grafted chitosan micelles as a nanocarrier system for drug-siRNA co-delivery to the lung cancer cells. Int J Biol Macromol, 118(Pt A), 857-863. doi:10.1016/j.ijbiomac.2018.06.114

Nguyen, D. D., \& Chang, S. (2017). Development of Novel Therapeutic Agents by Inhibition of Oncogenic MicroRNAs. Int J Mol Sci, 19(1). doi:10.3390/ijms19010065

Nguyen, T., Menocal, E. M., Harborth, J., \& Fruehauf, J. H. (2008). RNAi therapeutics: an update on delivery. Current opinion in molecular therapeutics, 10(2), 158-167.

Ni, S., Liu, Y., Tang, Y., Chen, J., Li, S., Pu, J., \& Han, L. (2018). GABAB receptor ligand-directed trimethyl chitosan/tripolyphosphate nanoparticles and their pMDI formulation for survivin siRNA pulmonary delivery. Carbohydr Polym, 179, 135-144. doi:10.1016/j.carbpol.2017.09.075

O'Toole, R. F., Shukla, S. D., \& Walters, E. H. (2015). TB meets COPD: An emerging global co-morbidity in human lung disease. Tuberculosis (Edinb), 95(6), 659-663. doi:10.1016/j.tube.2015.08.005

Ogawa, Y., \& Calhoun, W. J. (2006). The role of leukotrienes in airway inflammation. Journal of Allergy and Clinical Immunology, 118(4), 789-798.

Oh, B., \& Lee, M. (2014). Combined delivery of HMGB-1 box A peptide and S1PLyase siRNA in animal models of acute lung injury. Journal of Controlled Release, 175, 25-35.

Oh, Y.-K., \& Park, T. G. (2009). siRNA delivery systems for cancer treatment. Advanced drug delivery reviews, 61(10), 850-862. 
Okuda, T., Kito, D., Oiwa, A., Fukushima, M., Hira, D., \& Okamoto, H. (2013). Gene silencing in a mouse lung metastasis model by an inhalable dry small interfering RNA powder prepared using the supercritical carbon dioxide technique. Biological and Pharmaceutical Bulletin, 36(7), 1183-1191.

Otsuka, M., Shiratori, M., Chiba, H., Kuronuma, K., Sato, Y., Niitsu, Y., \& Takahashi, H. (2017). Treatment of pulmonary fibrosis with siRNA against a collagen-specific chaperone HSP47 in vitamin Acoupled liposomes. Exp Lung Res, 43(6-7), 271-282. doi:10.1080/01902148.2017.1354946

Pai, S., Lin, Y., Macaes, B., Meneshian, A., Hung, C., \& Wu, T. (2006). Prospects of RNA interference therapy for cancer. Gene therapy, 13(6), 464.

Peters, S. P., Ferguson, G., Deniz, Y., \& Reisner, C. (2006). Uncontrolled asthma: a review of the prevalence, disease burden and options for treatment. Respir Med, 100(7), 1139-1151. doi:10.1016/j.rmed.2006.03.031

Pirollo, K. F., Zon, G., Rait, A., Zhou, Q., Yu, W., Hogrefe, R., \& Chang, E. H. (2006). Tumor-targeting nanoimmunoliposome complex for short interfering RNA delivery. Human gene therapy, 17(1), 117-124.

Qiu, C., Peng, W., Shi, F., \& Zhang, T. (2012). Bottom-up assembly of RNA nanoparticles containing phi29 motor pRNA to silence the asthma STAT5b gene. Genet Mol Res, 11(3), 3236-3245.

Qiu, Y., Chow, M. Y. T., Liang, W., Chung, W. W. Y., Mak, J. C. W., \& Lam, J. K. W. (2017). From Pulmonary Surfactant, Synthetic KL4 Peptide as Effective siRNA Delivery Vector for Pulmonary Delivery. Mol Pharm, 14(12), 4606-4617. doi:10.1021/acs.molpharmaceut.7b00725

Qiu, Y., Lam, J., Leung, S., \& Liang, W. (2016). Delivery of RNAi therapeutics to the airways -from bench to bedside. Molecules, 21(9), 1249.

Ramakrishnan, L. (2012). Revisiting the role of the granuloma in tuberculosis. Nature Reviews Immunology, 12(5), 352.

Rapalli, V. K., Singhvi, G., Dubey, S. K., Gupta, G., Chellappan, D. K., \& Dua, K. (2018). Emerging landscape in psoriasis management: From topical application to targeting biomolecules. Biomedicine \& Pharmacotherapy, 106, 707-713.

Rennard, S. I., \& Vestbo, J. (2006). COPD: the dangerous underestimate of 15\%. Lancet, 367(9518), 12161219. doi:10.1016/s0140-6736(06)68516-4

Rettig, G. R., \& Behlke, M. A. (2012). Progress toward in vivo use of siRNAs-II. Molecular therapy, 20(3), 483-512.

Roberts, E. A., Chua, J., Kyei, G. B., \& Deretic, V. (2006). Higher order Rab programming in phagolysosome biogenesis. The Journal of cell biology, 174(7), 923-929.

Rodriguez-Roisin, R. (2000). Toward a Consensus Definition for COPD Exacerbations. CHEST, 117(5), 398S-401S. doi:10.1378/chest.117.5_suppl_2.398S

Rosas-Taraco, A. G., Higgins, D. M., Sanchez-Campillo, J., Lee, E. J., Orme, I. M., \& González-Juarrero, M. (2009). Intrapulmonary delivery of XCL1-targeting small interfering RNA in mice chronically infected with Mycobacterium tuberculosis. American journal of respiratory cell and molecular biology, 41(2), 136-145.

Rosas-Taraco, A. G., Higgins, D. M., Sánchez-Campillo, J., Lee, E. J., Orme, I. M., \& González-Juarrero, M. (2009). Intrapulmonary delivery of XCL1-targeting small interfering RNA in mice chronically infected with Mycobacterium tuberculosis. American journal of respiratory cell and molecular biology, 41(2), 136-145.

Rosas-Taraco, A. G., Higgins, D. M., Sánchez-Campillo, J., Lee, E. J., Orme, I. M., \& González-Juarrero, M. (2011). Local pulmonary immunotherapy with siRNA targeting TGF $\beta 1$ enhances antimicrobial capacity in Mycobacterium tuberculosis infected mice. Tuberculosis, 91(1), 98-106.

Rosell, R., \& Karachaliou, N. (2016). Large-scale screening for somatic mutations in lung cancer. Lancet, 387(10026), 1354-1356. doi:10.1016/s0140-6736(15)01125-3 
Rosenwasser, L. J., Zimmermann, N., Hershey, G. K., Foster, P. S., \& Rothenberg, M. E. (2003). Chemokines in asthma: cooperative interaction between chemokines and IL-13. Journal of Allergy and Clinical Immunology, 111(2), 227-242.

Sadowski, K., Kotulska, K., \& Jóźwiak, S. (2016). Management of side effects of mTOR inhibitors in tuberous sclerosis patients. Pharmacological Reports, 68(3), 536-542.

Sapey, E., \& Stockley, R. A. (2006). COPD exacerbations · 2: Aetiology. Thorax, 61(3), 250-258. doi:10.1136/thx.2005.041822

Sasaki, S., \& Guo, S. (2018). Nucleic Acid Therapies for Cystic Fibrosis. Nucleic Acid Ther, 28(1), 1-9. doi:10.1089/nat.2017.0696

Schultheis, B., Strumberg, D., Santel, A., Vank, C., Gebhardt, F., Keil, O., . . Khan, M. (2014). First-inhuman phase I study of the liposomal RNA interference therapeutic Atu027 in patients with advanced solid tumors. Journal of Clinical Oncology, 32(36), 4141-4148.

Sel, S., Henke, W., Dietrich, A., Herz, U., \& Renz, H. (2006). Treatment of allergic asthma by targeting transcription factors using nucleic-acid based technologies. Curr Pharm Des, 12(25), 3293-3304.

Shastri, M. D., Shukla, S. D., Chong, W. C., Dua, K., Peterson, G. M., Patel, R. P., . . O'Toole, R. F. (2018). Role of Oxidative Stress in the Pathology and Management of Human Tuberculosis. Oxid Med Cell Longev, 2018, 7695364. doi:10.1155/2018/7695364

Siegel, R., Naishadham, D., \& Jemal, A. (2012). Cancer statistics for hispanics/latinos, 2012. CA: a cancer journal for clinicians, 62(5), 283-298.

Silva Miranda, M., Breiman, A., Allain, S., Deknuydt, F., \& Altare, F. (2012). The tuberculous granuloma: an unsuccessful host defence mechanism providing a safety shelter for the bacteria? Clinical and Developmental Immunology, 2012.

Sioud, M. (2015). Overcoming the challenges of siRNA activation of innate immunity: design better therapeutic siRNAs. In RNA Interference (pp. 301-319): Springer.

Sorber, L., Zwaenepoel, K., Deschoolmeester, V., Van Schil, P. E., Van Meerbeeck, J., Lardon, F., ... Pauwels, P. (2017). Circulating cell-free nucleic acids and platelets as a liquid biopsy in the provision of personalized therapy for lung cancer patients. Lung Cancer, 107, 100-107. doi:10.1016/j.lungcan.2016.04.026

Staff, P. O. (2014). Correction: Gene Silencing of SOCS3 by siRNA Intranasal Delivery Inhibits Asthma Phenotype in Mice. PloS one, 9(8), e105924.

Sung, D. K., Kong, W. H., Park, K., Kim, J. H., Kim, M. Y., Kim, H., \& Hahn, S. K. (2013). Noncovalenly PEGylated CTGF siRNA/PDMAEMA complex for pulmonary treatment of bleomycin-induced lung fibrosis. Biomaterials, 34(4), 1261-1269.

Taratula, O., Kuzmov, A., Shah, M., Garbuzenko, O. B., \& Minko, T. (2013). Nanostructured lipid carriers as multifunctional nanomedicine platform for pulmonary co-delivery of anticancer drugs and siRNA. Journal of Controlled Release, 171(3), 349-357.

Tiseo, M., Bartolotti, M., Gelsomino, F., \& Bordi, P. (2010). Emerging role of gefitinib in the treatment of non-small-cell lung cancer (NSCLC). Drug design, development and therapy, 4, 81.

Tompkins, S. M., Lo, C.-Y., Tumpey, T. M., \& Epstein, S. L. (2004). Protection against lethal influenza virus challenge by RNA interference in vivo. Proceedings of the National Academy of Sciences, 101(23), 8682-8686.

Veilleux, D., Gopalakrishna Panicker, R. K., Chevrier, A., Biniecki, K., Lavertu, M., \& Buschmann, M. D. (2018). Lyophilisation and concentration of chitosan/siRNA polyplexes: Influence of buffer composition, oligonucleotide sequence, and hyaluronic acid coating. J Colloid Interface Sci, 512, 335-345. doi:10.1016/j.jcis.2017.09.084

Vogelstein, B., \& Kinzler, K. W. (2004). Cancer genes and the pathways they control. Nature medicine, 10(8), 789. 
Wakashin, H., Hirose, K., Maezawa, Y., Kagami, S.-i., Suto, A., Watanabe, N., . . Iwakura, Y. (2008). IL-23 and Th17 cells enhance Th2-cell-mediated eosinophilic airway inflammation in mice. American journal of respiratory and critical care medicine, 178(10), 1023-1032.

Wang, J., Lu, Z., Wientjes, M. G., \& Au, J. L.-S. (2010). Delivery of siRNA therapeutics: barriers and carriers. The AAPS journal, 12(4), 492-503.

Wang, J., Yang, K., Zhou, L., Wu, Y., Zhu, M., Lai, X., . . Huang, C. (2013). MicroRNA-155 promotes autophagy to eliminate intracellular mycobacteria by targeting Rheb. PLoS pathogens, 9(10), e1003697.

Wang, J., Zhu, M., Wang, L., Chen, C., \& Song, Y. (2019). Amphiregulin potentiates airway inflammation and mucus hypersecretion induced by urban particulate matter via the EGFR-PI3Ka-AKT/ERK pathway. Cellular signalling, 53, 122-131.

Wang, L., Huang, W., Zhang, L., Chen, Q., \& Zhao, H. (2018). Molecular pathogenesis involved in human idiopathic pulmonary fibrosis based on an integrated microRNA-mRNA interaction network. $\mathrm{Mol}$ Med Rep, 18(5), 4365-4373. doi:10.3892/mmr.2018.9456

Wang, X., Xu, W., Mohapatra, S., Kong, X., Li, X., Lockey, R. F., \& Mohapatra, S. S. (2008). Prevention of airway inflammation with topical cream containing imiquimod and small interfering RNA for natriuretic peptide receptor. Genetic vaccines and therapy, 6(1), 7.

Wark, P. A., Tooze, M., Powell, H., \& Parsons, K. (2013). Viral and bacterial infection in acute asthma and chronic obstructive pulmonary disease increases the risk of readmission. Respirology, 18(6), 9961002. doi:10.1111/resp.12099

Watts, J. K., \& Corey, D. R. (2010). Clinical status of duplex RNA. Bioorganic \& medicinal chemistry letters, 20(11), 3203-3207.

Whitehead, K. A., Langer, R., \& Anderson, D. G. (2009). Knocking down barriers: advances in siRNA delivery. Nature reviews Drug discovery, 8(2), 129.

Wu, W., Chen, H., Li, Y.-M., Wang, S.-Y., Diao, X., \& Liu, K.-G. (2014). Intranasal sirna targeting c-kit reduces airway inflammation in experimental allergic asthma. International journal of clinical and experimental pathology, 7(9), 5505.

Xie, Y., Kim, N. H., Nadithe, V., Schalk, D., Thakur, A., Kılıç, A., . . Merkel, O. M. (2016). Targeted delivery of siRNA to activated T cells via transferrin-polyethylenimine (Tf-PEI) as a potential therapy of asthma. Journal of Controlled Release, 229, 120-129.

Xie, Y., \& Merkel, O. M. (2015). Pulmonary delivery of siRNA via polymeric vectors as therapies of asthma. Archiv der Pharmazie, 348(10), 681-688.

Xu, C.-N., Tian, H.-Y., Wang, Y.-B., Du, Y., Chen, J., Lin, L., . . Chen, X.-S. (2017). Anti-tumor effects of combined doxorubicin and siRNA for pulmonary delivery. Chinese Chemical Letters, 28(4), 807812.

Xu, C.-X., Jere, D., Jin, H., Chang, S.-H., Chung, Y.-S., Shin, J.-Y., . . Chae, C.-H. (2008). Poly (ester amine)mediated, aerosol-delivered Akt1 small interfering RNA suppresses lung tumorigenesis. American journal of respiratory and critical care medicine, 178(1), 60-73.

Xu, C., Tian, H., Sun, H., Jiao, Z., Zhang, Y., \& Chen, X. (2015). A pH sensitive co-delivery system of siRNA and doxorubicin for pulmonary administration to B16F10 metastatic lung cancer. RSC Advances, 5(125), 103380-103385.

Xu, C., Tian, H., Wang, P., Wang, Y., \& Chen, X. (2016). The suppression of metastatic lung cancer by pulmonary administration of polymer nanoparticles for co-delivery of doxorubicin and Survivin siRNA. Biomaterials science, 4(11), 1646-1654.

Xu, P. Y., Kankala, R. K., Pan, Y. J., Yuan, H., Wang, S. B., \& Chen, A. Z. (2018). Overcoming multidrug resistance through inhalable siRNA nanoparticles-decorated porous microparticles based on supercritical fluid technology. Int J Nanomedicine, 13, 4685-4698. doi:10.2147/ijn.s169399 
Yoon, P. O., Park, J. W., Lee, C.-M., Kim, S. H., Kim, H.-N., Ko, Y., ... Kwon, T. (2016). Self-assembled micelle interfering RNA for effective and safe targeting of dysregulated genes in pulmonary fibrosis. Journal of Biological Chemistry, jbc. M115. 693671.

Youngren-Ortiz, S. R., Gandhi, N. S., España-Serrano, L., \& Chougule, M. B. (2016). Aerosol delivery of siRNA to the lungs. Part 1: Rationale for gene delivery systems. KONA Powder and Particle Journal, 33, 63-85.

Youngren-Ortiz, S. R., Gandhi, N. S., España-Serrano, L., \& Chougule, M. B. (2017). Aerosol Delivery of siRNA to the Lungs. Part 2: Nanocarrier-based Delivery Systems. KONA Powder and Particle Journal, 34, 44-69.

Yuan, Z. Q., Chen, W. L., You, B. G., Liu, Y., Yang, S. D., Li, J. Z., . . Zhang, X. N. (2017). Multifunctional nanoparticles co-delivering EZH2 siRNA and etoposide for synergistic therapy of orthotopic nonsmall-cell lung tumor. J Control Release, 268, 198-211. doi:10.1016/j.jconrel.2017.10.025

Zhang, C., Tang, N., Liu, X., Liang, W., Xu, W., \& Torchilin, V. P. (2006). siRNA-containing liposomes modified with polyarginine effectively silence the targeted gene. Journal of controlled release, 112(2), 229-239.

Zhang, D., Lee, H., Wang, X., Rai, A., Groot, M., \& Jin, Y. (2018). Exosome-Mediated Small RNA Delivery: A Novel Therapeutic Approach for Inflammatory Lung Responses. Mol Ther, 26(9), 2119-2130. doi:10.1016/j.ymthe.2018.06.007

Zhang, Z., Jiang, G., Yang, F., \& Wang, J. (2006). Knockdown of mutant K-ras expression by adenovirusmediated siRNA inhibits the in vitro and in vivo growth of lung cancer cells. Cancer biology \& therapy, 5(11), 1481-1486.

Zhang, Z., Yang, X., Zhang, Y., Zeng, B., Wang, S., Zhu, T., . . Yang, R. (2006). Delivery of telomerase reverse transcriptase small interfering RNA in complex with positively charged single-walled carbon nanotubes suppresses tumor growth. Clinical Cancer Research, 12(16), 4933-4939.

Table 1: siRNA delivery systems for targeted pulmonary therapy

\begin{tabular}{|c|c|c|c|c|c|}
\hline Delivery system & $\begin{array}{l}\text { siRNA } \\
\text { delivered }\end{array}$ & Target & $\begin{array}{l}\text { Route of } \\
\text { administration }\end{array}$ & Outcome & Reference \\
\hline $\begin{array}{l}\text { Polyethylenimine } \\
\text {-cis-aconitic } \\
\text { anhydride- } \\
\text { doxorubicin and } \\
\text { (B cell) Bcl2 } \\
\text { siRNA complex } \\
\text { nanoparticles }\end{array}$ & $\begin{array}{l}\text { Bcl-2 } \\
\text { siRNA }\end{array}$ & $\begin{array}{l}\text { Lung } \\
\text { cancer }\end{array}$ & Intratracheal & $\begin{array}{l}\text { The polyethyleneimine- } \\
\text { cis-aconitic anhydride- } \\
\text { doxorubicin/Bcl2 siRNA } \\
\text { complex nanoparticles } \\
\text { are for treating metastatic } \\
\text { lung cancer by pulmonary } \\
\text { delivery with low side } \\
\text { effects on the normal } \\
\text { tissues. }\end{array}$ & $\begin{array}{l}\text { (C. } \mathrm{Xu} \text { et } \\
\text { al., 2015) }\end{array}$ \\
\hline $\begin{array}{l}\text { Arginine-glycine- } \\
\text { aspartic } \\
\text { peptide } \\
\text { gold } \\
\text { nanoparticles }\end{array}$ & $\begin{array}{l}\text { c- } \\
\text { mycsiRNA }\end{array}$ & $\begin{array}{l}\text { Lung } \\
\text { cancer }\end{array}$ & Intratracheal & $\begin{array}{l}\text { c-myc-RGD gold } \\
\text { nanoparticles are capable } \\
\text { of targeting tumor cells, } \\
\text { significant tumor growth } \\
\text { inhibition, as well as } \\
\text { extended survival of mice } \\
\text { bearing tumors. }\end{array}$ & $\begin{array}{l}(\text { Conde et } \\
\text { al., 2013) }\end{array}$ \\
\hline
\end{tabular}




\begin{tabular}{|c|c|c|c|c|c|}
\hline $\begin{array}{l}\text { Glycerol } \\
\text { propoxylatetriacr } \\
\text { ylate and } \\
\text { spermine }\end{array}$ & \begin{tabular}{|l} 
Sodium- \\
dependent \\
phosphate \\
co- \\
transporter \\
2b(NPT2b) \\
siRNA \\
\end{tabular} & $\begin{array}{l}\text { Lung } \\
\text { cancer }\end{array}$ & Intratracheal & $\begin{array}{l}\text { siNPT2b successfully } \\
\text { suppressed lung cancer } \\
\text { growth and decreased } \\
\text { cancer cell proliferation } \\
\text { and angiogenesis, } \\
\text { facilitating apoptosis. }\end{array}$ & $\begin{array}{l}\text { (Hong et al., } \\
\text { 2014) }\end{array}$ \\
\hline $\begin{array}{l}\text { Chitosan dry } \\
\text { powder }\end{array}$ & $\begin{array}{l}\text { Luciferase } \\
\text { siRNA }\end{array}$ & $\begin{array}{l}\text { Lung } \\
\text { cancer }\end{array}$ & Intratracheal & $\begin{array}{l}\text { siRNA/chitosan powder } \\
\text { prepared using super } \\
\text { critical carbon dioxide } \\
\text { has an effective and } \\
\text { specific gene silencing } \\
\text { against the tumor cells } \\
\text { metastasized in the lungs } \\
\text { of mice }\end{array}$ & $\begin{array}{l}\text { (Okuda et } \\
\text { al., 2013) }\end{array}$ \\
\hline $\begin{array}{l}\text { Naked siRNA or } \\
\text { TransIT-TKO }\end{array}$ & $\begin{array}{l}\text { Phosphopr } \\
\text { oteinsiRN } \\
\text { A }\end{array}$ & $\begin{array}{l}\text { Parainfl } \\
\text { uenzavir } \\
\text { us } \\
\text { (PIV), } \\
\text { Respirat } \\
\text { ory } \\
\text { syncytia } \\
1 \\
\text { virus(R } \\
\text { SV) }\end{array}$ & Intranasal & $\begin{array}{l}\text { Animals were } \\
\text { successfully protected } \\
\text { from RSV and PIV } \\
\text { infections specifically }\end{array}$ & $\begin{array}{l}\text { (Bitko, } \\
\text { Musiyenko, } \\
\text { Shulyayeva, } \\
\& \quad \text { Barik, } \\
2005)\end{array}$ \\
\hline Naked siRNA & $\begin{array}{l}\text { Nucleocaps } \\
\text { id gene- } \\
\text { specificsiR } \\
\text { NA }\end{array}$ & $\begin{array}{l}\text { Viral } \\
\text { infectio } \\
\text { ns }\end{array}$ & Intranasal & $\begin{array}{l}\text { Significant reductions of } \\
\text { viral load were achieved } \\
\text { in both } \\
\text { prophylactic and } \\
\text { therapeutic regimens }\end{array}$ & $\begin{array}{l}\text { (Alvarez et } \\
\text { al., 2009) }\end{array}$ \\
\hline Oligofectamine & $\begin{array}{l}\text { Nucleocaps } \\
\text { id protein } \\
\text { and } \\
\text { Polymerase } \\
\text { acidic } \\
\text { protein } \\
\end{array}$ & $\begin{array}{l}\text { Influenz } \\
\text { a type A }\end{array}$ & $\begin{array}{l}\text { Intranasal and } \\
\text { hydrodynamic } \\
\text { injection }\end{array}$ & $\begin{array}{l}\text { Treated animals lung } \\
\text { virus titres were reduced } \\
\text { and protected from lethal } \\
\text { challenge } \\
\text { with highly pathogenic } \\
\text { viruses }\end{array}$ & $\begin{array}{l}\text { (Tompkins, } \\
\text { Lo, } \\
\text { Tumpey, \& } \\
\text { Epstein, } \\
\text { 2004) }\end{array}$ \\
\hline Naked siRNA & $\begin{array}{l}\text { Lymphotac } \\
\text { tin (XCL1) } \\
\text { siRNA }\end{array}$ & $\begin{array}{l}\text { Tubercu } \\
\text { losis }\end{array}$ & Intratracheal & $\begin{array}{l}\text { XCL1 expression in the } \\
\text { lungs was significantly } \\
\text { suppressed; decreased T } \\
\text { lymphocytes, } \\
\text { IFN- response and } \\
\text { disorganized } \\
\text { granulomatous } \\
\text { lesions and high fibrosis }\end{array}$ & $\begin{array}{l}\text { (Rosas- } \\
\text { Taraco, } \\
\text { Higgins, } \\
\text { Sánchez- } \\
\text { Campillo, et } \\
\text { al., 2009) }\end{array}$ \\
\hline Naked siRNA & $\begin{array}{l}\text { Transformi } \\
\text { ng growth } \\
\text { factor- } \beta 1 \\
\text { siRNA }\end{array}$ & $\begin{array}{l}\text { Tubercu } \\
\text { losis }\end{array}$ & Intratracheal & $\begin{array}{l}\text { Increased expression of } \\
\text { antimicrobial mediators, } \\
\text { with the reduced bacterial } \\
\text { load in the lungs of } \\
\text { treated mice }\end{array}$ & $\begin{array}{l}\text { (Rosas- } \\
\text { Taraco et } \\
\text { al., 2011) }\end{array}$ \\
\hline Naked siRNA & Suppressor & Asthma & Intranasal & Decrease in lung & (Staff, 2014) \\
\hline
\end{tabular}




\begin{tabular}{|c|c|c|c|c|c|}
\hline & $\begin{array}{l}\text { s of } \\
\text { cytokine } \\
\text { signaling } \\
\text { protein } 3 \\
\text { (SOCS) } \\
\text { siRNA }\end{array}$ & & & $\begin{array}{l}\text { eosinophilia, } \\
\text { normalization of } \\
\text { hyperresponsiveness, } \\
\text { increase in mucus } \\
\text { secretion and reduction in } \\
\text { collagen deposition in the } \\
\text { lungs. }\end{array}$ & \\
\hline Naked siRNA & $\begin{array}{l}\text { Interleukin } \\
-4 \quad \text { siRNA } \\
\text { and } \\
\text { Phosphopr } \\
\text { otein } \\
\text { siRNA }\end{array}$ & Asthma & Intranasal & $\begin{array}{l}\text { Esinophilia in } \\
\text { bronchoalveolar lavage } \\
\text { fluid, } \\
\text { hyperresponsiveness and } \\
\text { airway inflammation } \\
\text { were } \\
\text { significantly reduced }\end{array}$ & $\begin{array}{l}\text { (Khaitov et } \\
\text { al., 2014) }\end{array}$ \\
\hline Naked siRNA & $\begin{array}{l}\text { Signal } \\
\text { transducer } \\
\text { and } \\
\text { activator of } \\
\text { transcriptio } \\
\mathrm{n} \text { factor } 6 \\
\text { (STAT6) } \\
\text { siRNA }\end{array}$ & Asthma & $\begin{array}{l}\text { Intratracheal and } \\
\text { intranasal }\end{array}$ & $\begin{array}{l}\text { Allergen-induced lung } \\
\text { inflammation was } \\
\text { significantly reduced and } \\
\text { Expression of key } \\
\text { cytokines (IL-4, IL-13) } \\
\text { and } \\
\text { allergen-induced } \\
\text { inflammation in lung } \\
\text { tissues were } \\
\text { significantly reduced }\end{array}$ & $\begin{array}{l}\text { (Darcan- } \\
\text { Nicolaisen } \\
\text { et al., 2009) }\end{array}$ \\
\hline Naked siRNA & $\begin{array}{l}\text { Receptor- } \\
\text { interacting } \\
\text { protein } 2 \\
\text { (Rip2) } \\
\text { siRNA }\end{array}$ & Asthma & Intratracheal & $\begin{array}{l}\text { Ovalbumin-induced } \\
\text { cytokine release, } \\
\text { inflammatory cell } \\
\text { infiltration } \\
\text { and mucus } \\
\text { hypersecretionwas } \\
\text { inhibited. elevation of } \\
\text { serum Ovalbumin- } \\
\text { specific IgE level was } \\
\text { markedly suppressed }\end{array}$ & $\begin{array}{l}\text { (Goh et al., } \\
\text { 2013) }\end{array}$ \\
\hline Naked siRNA & $\begin{array}{l}\text { cluster of } \\
\text { differentiati } \\
\text { on } 86 \\
\text { (CD86) } \\
\text { siRNA }\end{array}$ & Asthma & Intratracheal & $\begin{array}{l}\text { Ovalbumin-induced } \\
\text { airway eosinophilia, } \\
\text { airway } \\
\text { hyperresponsiveness, and } \\
\text { cytokines } \\
\text { production was reduced }\end{array}$ & $\begin{array}{l}\text { (Asai-Tajiri } \\
\text { et al., 2014) }\end{array}$ \\
\hline Naked siRNA & $\begin{array}{l}\text { Spleen } \\
\text { tyrosine } \\
\text { kinase } \\
\text { (syk) } \\
\text { siRNA }\end{array}$ & Asthma & Intranasal & $\begin{array}{l}\text { siRNA administration by } \\
\text { intranasal route inhibited } \\
\text { inflammatory cells in the } \\
\text { bronchoalveolar lavage } \\
\text { fluid(BALF) of allergen } \\
\text { sensitized mice. }\end{array}$ & $\begin{array}{l}\text { (Z.-Y. } \\
\text { Huang, } \\
\text { Kim, Kim- } \\
\text { Han, Indik, } \\
\text { \& Schreiber, } \\
\text { 2013) }\end{array}$ \\
\hline Naked siRNA & c-kitsiRNA & Asthma & Intranasal & $\begin{array}{l}\text { Airway mucus secretion } \\
\text { and eosinophil infiltration } \\
\text { in BALFwas effectively } \\
\text { reduced. C-kit further }\end{array}$ & $\begin{array}{l}\text { (Wu et al., } \\
2014)\end{array}$ \\
\hline
\end{tabular}




\begin{tabular}{|c|c|c|c|c|c|}
\hline & & & & $\begin{array}{l}\text { reduced the production of } \\
\text { stem cell factor, IL- } 4 \text {, and } \\
\text { IL- } 5 \text {, but had no effect on } \\
\text { interferon- } \gamma(\text { IFN- } \gamma) \\
\text { generation }\end{array}$ & \\
\hline $\begin{array}{l}\text { Transferrin } \\
\text { polyethylenimine } \\
\text { (Tf-PEI) }\end{array}$ & $\begin{array}{l}\text { Fluorescent } \\
\text { ly } \\
\text { labeledsiR } \\
\text { NA } \\
\end{array}$ & Asthma & Intratracheal & $\begin{array}{l}\text { Tf-PEIpolyplexes } \\
\text { selectively delivered } \\
\text { siRNA to activated } \\
\text { T cells }\end{array}$ & $\begin{array}{l}\text { (Xie et al., } \\
2016)\end{array}$ \\
\hline $\begin{array}{lr}\text { R3V6 peptides } \\
\text { were used as a } \\
\text { carrier. (Ternary } \\
\text { complex } & \text { of } \\
\text { siS1PLyase, } \\
\text { HMGB1A, and } \\
\text { R3V6 } \\
\text { produced } \\
\text { charge } \\
\text { interaction) }\end{array}$ & $\begin{array}{l}\text { siS1PLyase } \\
\text { /HMGB1A } \\
\text { /R3V6 } \\
\text { ternary } \\
\text { complex }\end{array}$ & $\begin{array}{l}\text { Acute } \\
\text { lung } \\
\text { injury }\end{array}$ & Intratracheal & $\begin{array}{l}\text { siS1PLyase/HMGB1A/R } \\
3 \text { V6 complex reduced the } \\
\text { levels- } 6 \text { and TNF- } \alpha \text { more } \\
\text { efficiently compared to } \\
\text { HMGB1A alone and } \\
\text { siS1PLyase/R3V6 } \\
\text { complexin } \\
\text { lipopolysaccharides } \\
\text { activated macrophages } \\
\text { and reduced } \\
\text { the inflammatory } \\
\text { response and apoptosis in } \\
\text { acute lung injury }\end{array}$ & $\begin{array}{l}\text { (B. Oh \& } \\
\text { Lee, 2014) }\end{array}$ \\
\hline $\begin{array}{l}\text { Naked siRNA, } \\
\text { i.v, liposomes }\end{array}$ & $\begin{array}{l}\text { Tumor } \\
\text { necrosis } \\
\text { factor- } \alpha\end{array}$ & $\begin{array}{l}\text { Acute } \\
\text { lung } \\
\text { injury }\end{array}$ & Intratracheal & $\begin{array}{l}\text { Systemic injection but not } \\
\text { intratracheal delivery of } \\
\text { TNF- } \alpha \text { siRNA } \\
\text { significantly reduced the } \\
\text { incidence of acute lung } \\
\text { injury. Results suggest } \\
\text { pulmonary endothelial } \\
\text { and/or other possible } \\
\text { vascular resident cells, } \\
\text { not epithelial cells, play a } \\
\text { greater role in mediating } \\
\text { the TNF- } \alpha \text { priming } \\
\text { response in } \\
\text { hemorrhage/sepsis- } \\
\text { induced acute lung injury. }\end{array}$ & $\begin{array}{l}\text { (Lomas- } \\
\text { Neira, Perl, } \\
\text { Venet, } \\
\text { Chung, \& } \\
\text { Ayala, } \\
\text { 2012) }\end{array}$ \\
\hline Naked siRNA & $\begin{array}{l}\text { Transformi } \\
\text { ng growth } \\
\text { factor- } \beta 1 \\
\text { (TGF- } \beta 1 \text { ) } \\
\text { siRNA }\end{array}$ & $\begin{array}{l}\text { Pulmon } \\
\text { ary } \\
\text { fibrosis }\end{array}$ & Intratracheal & $\begin{array}{l}\text { Levels of inflammatory } \\
\text { cytokines, including IFN- } \\
\alpha \text { and IFN- } \beta \text {, were not } \\
\text { significantly affected, } \\
\text { whereas TGF- } \beta 1 \text { was } \\
\text { significantly inhibited. }\end{array}$ & $\begin{array}{l}\text { (Corina N } \\
\text { D'Alessandr } \\
\text { o-Gabazza } \\
\text { et al., 2012) }\end{array}$ \\
\hline $\begin{array}{l}\text { PEGylated } \\
\text { poly(dimethylami } \\
\text { no)ethylmethacry } \\
\text { late } \\
\text { (PDMAEMA) }\end{array}$ & \begin{tabular}{|l|} 
Connective \\
tissue \\
growth \\
factor \\
(CTGF) \\
siRNA \\
\end{tabular} & $\begin{array}{l}\text { Pulmon } \\
\text { ary } \\
\text { fibrosis }\end{array}$ & Intratracheal & $\begin{array}{l}\text { There was a reduction in } \\
\text { collagen deposition, } \\
\text { inflammatory cytokines } \\
\text { production and drastic } \\
\text { attenuation of pulmonary } \\
\text { fibrosis }\end{array}$ & $\begin{array}{l}\text { (Sung et al., } \\
\text { 2013) }\end{array}$ \\
\hline
\end{tabular}




\begin{tabular}{|c|c|c|c|c|c|}
\hline $\begin{array}{l}\text { Self-assembled } \\
\text { micelle } \\
\text { interfering RNA } \\
\text { (siRNA) } \\
\text { nanoparticles }\end{array}$ & $\begin{array}{l}\text { Amphiregu } \\
\text { lin (AR) } \\
\text { and } \\
\text { connective } \\
\text { tissue } \\
\text { growth } \\
\text { factor } \\
\text { (CTGF) } \\
\text { targeting } \\
\text { siRNA } \\
\end{array}$ & $\begin{array}{l}\text { Pulmon } \\
\text { ary } \\
\text { fibrosis }\end{array}$ & $\begin{array}{l}\text { Intratracheal/intra } \\
\text { venous }\end{array}$ & $\begin{array}{l}\text { Collagen accumulation } \\
\text { was significantly reduced } \\
\text { and lung function was } \\
\text { substantially restored in } \\
\text { TGF- } \beta \text { transgenic mice. }\end{array}$ & $\begin{array}{l}\text { (Yoon et al., } \\
2016 \text { ) }\end{array}$ \\
\hline $\begin{array}{l}\text { Chitosan-based } \\
\text { siRNA } \\
\text { nanoparticle }\end{array}$ & $\begin{array}{l}\text { siRNA } \\
\text { specific to } \\
\text { the } \\
\mathrm{BCR} / \mathrm{ABL}- \\
1 \text { junction } \\
\text { sequence }\end{array}$ & $\begin{array}{l}\text { Potentia } \\
1 \text { of } \\
\text { chitosan } \\
\text { nanocar } \\
\text { riers }\end{array}$ & Nasal & $\begin{array}{l}\text { In bronchiole epithelial } \\
\text { cells of transgenic EGFP } \\
\text { (endogenous enhanced } \\
\text { green fluorescent protein) } \\
\text { mice. }\end{array}$ & $\begin{array}{l}\text { (Howard et } \\
\text { al., 2006) }\end{array}$ \\
\hline $\begin{array}{l}\text { Spray dried naked } \\
\text { siRNA using L- } \\
\text { leucine } \\
\text { dispersion } \\
\text { enhancer }\end{array}$ & $\begin{array}{l}\text { siRNA } \\
\text { targeting } \\
\text { interleukin } \\
10\end{array}$ & $\begin{array}{l}2 \% \mathrm{~W} / \\
\mathrm{W} \\
\text { siRNA } \\
\text { develop } \\
\text { ed into } \\
\text { an } \\
\text { inhalabl } \\
\text { e dry } \\
\text { powder }\end{array}$ & Not applicable & $\begin{array}{l}\text { The integrity of siRNA } \\
\text { was successfully retained } \\
\text { after spray drying. Spray } \\
\text { dried powder were crystal } \\
\text { in nature with low } \\
\text { moisture levels traits } \\
\text { stable formulation. }\end{array}$ & $\begin{array}{l}\text { (Chow et } \\
\text { al., 2017) }\end{array}$ \\
\hline
\end{tabular}

